\title{
Darius Milhaud's Machines Agricoles as Post-Pastoral
}

\author{
LOUIS K. EPSTEIN
}

"Not a single critic understood what drove me to write these songs," wrote Darius Milhaud of his song cycle Machines agricoles (1919). ${ }^{1}$ Milhaud chose not to acknowledge that his critics' confusion was largely justified. In Machines agricoles, the typical chamber orchestration and polytonality of Milhaud's early works served as a setting for highly unusual texts: excerpts from a farm machinery catalogue. From its opening moments, Machines agricoles dares listeners not to laugh at its central conceit. As viola, clarinet, and flute present gentle, pentatonic melodies in different keys, the soprano earnestly sings the text, "The harvester is used particularly in places where the straw is of poor quality; it is a machine that, thanks to its broad blade, makes it possible to harvest twelve to fifteen hectares per day."2

Example 1: Milhaud's Machines agricoles, beginning of first movement, "La Moissonneuse Espigadora."

Listen at: http://dx.doi.org/10.3998/mp.9460447.0008.204

Given Milhaud's straight-faced setting for such an unusual text, it is easy to understand why the young composer was accused of "leg-pulling," "intentional eccentricity," and composing the piece "as if out of defiance." Machines agricoles quickly came to stand for Milhaud's oeuvre and aesthetic as a whole, and not to his benefit. In a 1925 retrospective on Milhaud in La Revue musicale, Boris de Schloezer felt obliged to defend the piece, declaring, "Enough laughing about these machines!" ${ }^{4}$ More recently, scholars have referred to Machines agricoles as a "hoax" and characterized it as an exercise in musical irony, citing the "mismatch" between text and music, or the "incongruous," "Dadaist" juxtaposition of the mundane

\footnotetext{
${ }^{1}$ Darius Milhaud, Ma Vie heureuse (Paris: Belfond, 1973), 104. “Aucun critique ne comprit ce qui m'avait poussé à écrire ces oeuvres." All translations are my own unless otherwise noted. An earlier version of this article was presented at the 2013 annual meeting of the Society for French Historical Studies as part of the panel "Nature and Technology in Early TwentiethCentury French Music." I am grateful to Noel Verzosa, Samuel Dorf, Colin Roust, and Leslie Sprout for their comments during the panel, and I am particularly grateful to Noel Verzosa and Christopher Moore for sharing unpublished conference papers that informed my thinking about Machines agricoles. Thanks go to Luke Simonson for transcribing the score examples. Finally, I would like to thank Sindhu Revuluri, Matthew Mugmon, Tyler Kinnear, Eric Drott, and the anonymous readers for their helpful feedback throughout various stages of this project.

${ }^{2}$ Milhaud, Machines Agricoles (Vienna: Universal Edition, 1926), 3-5. "La moissonneuse espigadora est employée surtout dans les pays où la paille n'a pas grande valeur; c'est une machine qui grâce à sa grande coupe permet de faire de douze à quinze hectares par jour."

${ }^{3}$ Milhaud reported these criticisms in his autobiography, writing, "Chaque fois que l'on voulut prouver mon gout accentué pour la fumisterie [fraud] et l'excentricité, on cita les Machines agricoles” (Ma Vie Heureuse, 105). For evidence that Milhaud's later reputation rested largely on the initial reception if Machines agricoles, see Réné Dumesnil, La Musique en France entre les deux guerres, 1918-1939 (Paris: Editions du Milieu du Monde, 1946), 174.

${ }^{4}$ Boris de Schloezer, "Darius Milhaud," La Revue musicale 6, no. 5 (March 1, 1925): 251-76, reprinted in Boris de Schloezer, Comprendre la musique: Contributions à La Nouvelle revue française et à La Revue musicale (1921-1956), ed. Timothée Picard (Rennes: Presses Universitaires de Rennes, 2011), 299.
} 
with the poetic. ${ }^{5}$ Yet Milhaud rejected all of these descriptions, arguing in his autobiography, "I have never understood how sensible people could make themselves believe that given the painful tenacity that accompanies all creativity, an artist would spend his time working with the sole purpose of mocking certain audience members." ${ }^{6}$ If it was not exclusively meant to mock his audience, what other purpose might the piece serve?

The subtitle for Machines agricoles - Six Pastorales pour une voix et sept instruments - adds to the seeming irony of Milhaud's song cycle. Each movement takes its title from a different piece of farm machinery. Catalogue descriptions of this machinery became Milhaud's texts: La Moissonneuse Espigadora (harvester), La Faucheuse (mower), La Lieuse (binder), La Déchameuse-semeuse-enfouisseuse (harrow-plough seeder-burier), La Fouilleuse-draineuse (sub-soil and draining plough), La Faneuse (tedder). According to Milhaud, the "pastoral" designation for his piece reflected one of two sources of inspiration:

the spirit that brought them to life was similar to the one that motivated composers of the past to sing the praises of the field harvest, the grape harvest, the "good farmer," Honegger to glorify a locomotive and Fernand Léger to exalt machines. ${ }^{7}$

Milhaud's explanation hardly clarifies the matter. His song cycle offers a seemingly paradoxical celebration of both rural pastimes and the machinery associated with modern life. Decades later, however, his widow echoed Milhaud's indignity at the cruel labels erroneously applied to his efforts. In an interview with Roger Nichols, Madeleine Milhaud insisted that the six movements of Machines agricoles were "not at all satirical or anything of that type: they were like pastorales." ${ }^{8}$ It is difficult to take the Milhauds at their word when the autobiographical chapter in which the composer describes Machines agricoles is entitled "Musique d'ameublement et de catalogue" ("Furniture and Catalogue Music"). Furthermore, Deborah Mawer has connected the "light-hearted and theatrical approach" of the work with Milhaud's choice of dedicatees, including Jean Cocteau, Arthur Honegger, Francis Poulenc, Germaine Tailleferre, Louis Durey, and Georges Auric. ${ }^{9}$ There is no question that the work is steeped in sophisticated irony, perhaps claiming a third strain of inspiration in the plethora of similarly provocative, seemingly nonsensical works

\footnotetext{
${ }^{5}$ Eveline Hurard-Viltard, Le groupe des Six ou le matin d'un jour de fête (Paris: Méridiens/Klinksieck, 1987), 175. Roger Nichols, The Harlequin Years (Berkeley: University of California Press, 2002), 238. Deborah Mawer, Darius Milhaud: Modality \& Structure in Music of the 1920s (Aldershot: Ashgate Press, 1997), 87. For one exploration of Milhaud's interest in nature, especially as represented by the exotic "wilderness" of the New World, see Wilfrid Mellers, Singing in the Wilderness: Music and Ecology in the Twentieth Century (Urbana: University of Illinois Press, 2001), 68-80. Mellers does not discuss Machines agricoles, perhaps signifying that he, too, finds little of the "natural" in the work.

${ }^{6}$ Milhaud, Ma Vie heureuse, 105. “Je n'ai jamais compris comment des êtres sensés pouvaient s'imaginer qu'un artiste passerait son temps à travailler, avec l'acharnement douloureux qui accompagne toute création, dans le seul but de se moquer de quelques-uns d'entre eux."

${ }^{7}$ Ibid. "l'esprit qui les animait était semblable à celui qui motiva les compositeurs à chanter autrefois les moissons, les vendanges, le 'bon laboureur,' Honegger à glorifier une locomotive et Fernand Léger à exalter des machines.” For another, similar complaint about critics' tendencies to dismiss Milhaud as a jester, see the letter from Milhaud to Paul Collaer, 24 May 1921, Paul Collaer: Correspondance avec mes amis musiciens, ed. Robert Wangermée (Liège: Pierre Mardaga, 1996), 80. “Le conférencier qui dit que j'écris pour taquiner le public mérite un coup de pied quelque part. Je méprise bien trop le public et le conférencier en question. Si je m'occupais' du public, ce serait pour avoir de succès. Je me fous de succès. Je ne tiens pas du tout à ce que l'acrobate réussisse son tour. Je tiens à travailler beaucoup, simplement."

${ }^{8}$ Nichols follows Mme. Milhaud's assertion with the correction, “One is tempted to say 'paradoxical pastorales"” (The Harlequin Years, 238).

${ }^{9}$ Deborah Mawer connects the "pompous tone of the text" and Milhaud's "light-hearted and theatrical approach" to the work's tongue-in-cheek affect and all of the above to its dedication, arguing, "Surely there has to be significance also in the dedication of these six songs to the other members of that publically acknowledged clique of 'les Six', together with their impresario Jean Cocteau." Darius Milhaud, 87.
} 
based on unusual texts produced by Erik Satie and Francis Poulenc (among others) in the late 1910s. ${ }^{10}$

At the same time, Milhaud's defense of Machines agricoles as rooted in the pastoral tradition cannot be ignored. In Ma Vie heureuse, instead of describing farm machinery in terms of industry, efficiency, or precision, Milhaud dubbed them "great, colorful, iron insects." 11 His choice of zoomorphic metaphor strengthens the justification for a reading of Machines agricoles that takes the work's pastoral bona fides seriously. To the extent that the piece is about machines, those machines are defined by their relationship with rural rather than urban spaces. Much as the insects to which Milhaud compares them, farm machinery participated in the rural spaces of early twentieth-century France by participating in the life cycle of cultivation and harvest. In these ways, Milhaud's music satisfies Lawrence Buell's definition of pastoralism as work that "celebrates the ethos of nature/rurality against the ethos of the town or city." 12

Taking Machines agricoles seriously as a pastoral means situating farm machinery within a storied pantheon of pastoral symbols. From the mythological (fauns and nymphs) to carbon-based life (shepherds and birds) to inanimate entities (fields, forests, and rivers), the pastoral has long accepted a variety of actors and objects_-but rarely man-made technology, other than perhaps the shepherd's crook. The spirit of the pastoral, however, has always admitted the possibility of the man-made. Literary scholars Leo Marx and Raymond Williams have noted that the pastoral tradition began as critical commentary on contemporary rural issues; the idealization of rural space as an escape from the modern developed much later. ${ }^{13}$ In his First Eclogue, Virgil—arguably the progenitor of the pastoral tradition—spun a tale infused with political commentary on property disputes and the logistical challenges of subsistence agriculture. At its origins, then, the pastoral properly consisted of interactions (or more precisely, tensions) between human and natural "agents" in idealized spaces. In this context, Milhaud's choice of subjects for his song cycle seems more apt. Farm machines participated in the "ecology" of farm life, where ecology (as defined by Aaron Allen and others) includes human and nonhuman elements in contrast with a conception of "environment" that includes only nonhuman, non-man-made agents. ${ }^{14}$ Thus Machines agricoles can be

\footnotetext{
${ }^{10}$ In particular, critics and audiences smelled a joke in the seriousness of the subject matter and the austere, neoclassical musical language of Satie's cantata Socrate (1918). Poulenc's dissonant, primitivist Rapsodie nègre (1917) employed a similar ensemble and included a movement entitled "pastorale," while two other movements set nonsensical, inauthentic "African" texts by an invented poet named "Makoko Kangourou."

${ }^{11}$ Milhaud, Ma Vie heureuse, 104. “. . . j’avais été tellement saisi par la beauté de ces grands insects de fer multicolores, magnifiques frères modernes de la charrue et de la faux."

${ }^{12}$ Lawrence Buell, The Environmental Imagination: Thoreau, Nature Writing, and the Formation of American Culture (Cambridge, MA: Harvard University Press, 1995), 32.

${ }^{13}$ Leo Marx, The Machine in the Garden: Technology and the Pastoral Ideal in America (Oxford: Oxford University Press, 1964 [2000]), 20-23. In an essay entitled "Pastoral and Counter-Pastoral," Raymond Williams notes that Virgil's First Eclogue was criticized by certain "theoreticians . . . because it included the real social conditions of land tenure." See Raymond Williams, "Pastoral and Counter-Pastoral," Critical Quarterly 10 (1967): 278. Critics of Milhaud's work, too, continue to balk at what they perceived as a disconnect in the piece between its modernist realism and the ostensible sentimentality of the pastoral tradition. Milhaud's music is caught in a catch-22 that Holly Watkins has discussed with respect to Stephen Albert's Symphony: RiverRun (1983). Neo-romantic tonal language expresses pastoral tropes clearly, but attracts criticism for oversentimentality (or worse, pandering to paying audiences). See Holly Watkins, "The Pastoral After Environmentalism: Nature and Culture in Stephen Albert's Symphony: RiverRun," Current Musicology 84 (Fall 2007): 7-24. But Milhaud's music, which primarily rejects common practice tonality, is accused of making a mockery of pastoral conventions; Machines agricoles is insufficiently sentimental to earn the "pastoral" label.

${ }^{14}$ Aaron Allen defines the two terms as follows: "Environment is the nonhuman physical world, i.e., the natural world with all its living creatures and nonliving objects and natural processes (while useful, this conception can promote a problematic human-other duality). Ecology, on the other hand, is holistic, relating to the 'eco-' prefix (from the Greek root oikos, 'household'), and constituting the web of relationships of all living organisms, including humans, with their contextual physical environments." Aaron Allen, "Ecomusicology: Ecocriticism and Musicology," Journal of the American
} 
seen to represent a return to the origins of the pastoral tradition by offering a perspective on the contemporary rural life Milhaud knew, just as Virgil's Eclogues depicted the rural life of his own time.

With the possibility of Milhaud's sincerity in mind, ecocriticism offers a helpful lens through which to reexamine Machines agricoles. Scholarship on pastoral literature identifies two predominant modes or aims within the genre. In the first, pastoral tropes signal social and aesthetic escapism, symptomatic of the desire for what Roger Sales has described in terms of "five Rs": "refuge, reflection, rescue, requiem, and reconstruction." Escapist pastorals sublimate anxieties around modernization and the loss of traditional, rural ways of life by luxuriating in the familiar and the conventional. In the groundbreaking ecocritical study The Machine in the Garden: Technology and the Pastoral Ideal in America, first published in 1964, Leo Marx characterized escapist pastoral works in terms of the "popular and sentimental" affects they emphasized. ${ }^{16}$ Terry Gifford has defined the most common and least contentious strain of pastoralism as "a retreat from politics into an apparently aesthetic landscape that is devoid of conflict and tension." 17 In music, this utopian mode of pastoral finds expression in a number of clichés, including harmonic stasis (notably drones), instrumentation (English horn and flute solos), and "folk"-inspired melodies.

Milhaud knew well a number of pieces that manifested the escapist strain of pastoralism. First among these was Chabrier's Pièces pittoresques (1880), which also inspired Francis Poulenc's fascination with the pastoral. ${ }^{18}$ In subsequent music inspired by Symbolist approaches to the escapist pastoral, the geographic and social distance between urban and rural is often amplified by an additional distance between technologized present and rustic, even primitive past. For example, both Debussy's Prélude à l'après-midi d'un faun (1894) and Ravel's Daphnis et Chlöé (1912) indulge in timbres and harmonic play deeply indebted to exoticist constructions that conflate the distant past with the "primitive" music of contemporary, non-Western cultures. ${ }^{19}$ Milhaud's music, which primarily rejects the tonally centered, lush orchestration of these pastoral predecessors, is accused by scholars and critics of making a mockery of pastoral conventions; Machines agricoles has long been considered insufficiently sentimental and escapist to earn the "pastoral" label.

A second, more critical mode identified by literary scholars corresponds closely to the ostensible pastoralism of Machines agricoles. Leo Marx contrasted the "popular and sentimental" affects of escapist pastorals with the "imaginative and complex" tendencies of others. ${ }^{20}$ In Literature and the Pastoral, Andrew Ettin describes the second mode as "an ironic form, based on a perceivable distance between the alleged and the implied," while David James and Philip Tew call it a realm of "certain intersections full of

\footnotetext{
Musicological Society 64, no. 2 (Summer, 2011): 392.

${ }^{15}$ Roger Sales, English Literature in History 1780-1830: Pastoral and Politics (London: Hutchinson, 1983$), 17$.

${ }^{16}$ Marx, The Machine in the Garden, 5.

17 Terry Gifford, Pastoral (New York: Routledge, 1999), 11.

${ }^{18}$ In an unpublished paper entitled "Poulenc's Versions of Pastoral" presented at the conference Rethinking Poulenc: 50 Years On (Keele University, June 22, 2014), Christopher Moore explored the relationships between Poulenc's pastoral works of the 1910s and 1920s and his oft-acknowledged fascination with Chabrier's Pièces pittoresques.

${ }^{19}$ I am grateful to Noel Verzosa for pointing out that Milhaud also knew well another work by Debussy-the Sonata for Flute, Viola and Harp of 1915-that adopted a different pastoral aesthetic from that of Prélude à l'après-midi d'un faun. By the time Debussy wrote the first movement of the Sonata, which was titled "Pastorale," the aging composer's approach to musical depictions of nature had shifted away from the exoticizing sounds of pentatonicism and gamelan to a more ascetic neoclassicism. Nevertheless, as James Parakilas has argued, the original instrumentation for the sonata (flute, oboe, harp) would have evoked ancient Greece and its syrinx, aulos, and kithara just as surely as Prélude de l'après-midi d'un faun did with its subject matter. Thus Debussy continued to conflate pastoralism with a distant, exoticized past, encoding an escapist version of the pastoral within his music.

${ }^{20}$ Marx, The Machine in the Garden, 5.
} 
innate contradictions, which it attempts to partially resolve or mediate." ${ }^{21}$ In opposition to the "escapist" pastoral, Terry Gifford summarized the second mode as a "political critique of present society, or ... a dramatic form of unresolved dialogue about the tensions in that society." 22 In light of these readings, Milhaud's Machines agricoles might be understood as an exemplary pastoral, rather than an exceptional one. The work's irony and humor function doubly, satisfying a typical modernist desire to reject conventions or provoke audiences (accomplished here through the choice of text) but also forcing consideration of the ecological contradictions of rural life. As a traditional pastoral-an escape from an increasingly industrial, urban world into an idealized, sensual, and imagined rural past-Machines agricoles earns its reputation as a joke. But considered as a musical exploration of what Gifford has called the "post-pastoral," in which artists celebrate nature without idealizing it, and in which "nature" is depicted as irrevocably integrated with the human world, Milhaud's song cycle opens to new interpretations. $^{23}$

In his authoritative study of the pastoral, Gifford coined the term "post-pastoral" to include literature that is neither unselfconsciously celebratory of nor exclusively hostile toward traditional pastoral conventions. Instead, the post-pastoral "finds a language to outflank those dangers with a vision of accommodated humans, at home in the very world they thought themselves alienated from by their possession of language." 24 Inherently ecocritical, the post-pastoral acknowledges "the urgent need for responsibility and, indeed, advocacy" for the welfare of nature, however defined. ${ }^{25}$ Among other attributes, authors of post-pastoral literature evince awe and respect for the natural world; they recognize cyclical dyads like birth-death, creation-destruction, growth-decay; and they complicate the opposition of nature and culture, showing how the two are more linked than separate. Just as Gifford analyzes these characteristics in literature stretching back to the nineteenth century, we can observe them at work in Machines agricoles.

Drawing on Gifford's notion of the post-pastoral, I argue that Milhaud's invocation of the pastoral genre is not merely an incongruous, Dadaist provocation. Rather, it engages in productive critique of the pastoral tradition while simultaneously participating in politically inflected discourse concerning the challenges facing rural France in the early part of the twentieth century. In numerous ways, Milhaud's music points away from the superficial celebration of mechanism apparent in the catalogue texts he sets. A close reading of Machines agricoles reveals numerous musical references to the pastoral tradition, albeit in a context that updates (and in some cases rejects) escapist idealizations of rural ecologies. Reading Machines agricoles in terms of traditional and innovative pastoral tropes helps to foreground the work's political context—and by extension, the political contexts latent throughout the history of pastoral music.

Milhaud composed Machines agricoles during a time when ruralist politics and French anxieties over its agricultural heritage had been gaining visibility for decades in a process that only intensified after the First World War. While scholars of interwar French music have pointed to the use of folk or provincial sources as evidence of conservative political views fueled by romantic nostalgia, I propose that Milhaud's

\footnotetext{
${ }^{21}$ Andrew V. Ettin, Literature and the Pastoral (New Haven, CT: Yale University Press, 1984), 12; David James and Philip Tew, eds., New Versions of Pastoral: Post-Romantic, Modern, and Contemporary Responses to Tradition (Madison, WI: Fairleigh Dickinson University Press, 2009), 13.

${ }^{22}$ Gifford, Pastoral, 11.

23 Ibid., 146-74.

${ }^{24}$ Ibid., 149.

25 Ibid.
} 
pastoralism celebrates the present more than the past, anticipating a future technological nostalgia for the simple machines of the early twentieth century. ${ }^{26}$ In other words, unlike explicitly Futurist celebrations of machines like the ones Milhaud cites in his autobiography, Machines agricoles glances with apprehension at the increasing ubiquity of machines far more disruptive to traditional ways of life than reaper-bindersowers. To investigate the pastoral pretentions of Machines agricoles is not merely to offer a counterreading of the piece, but also to situate the piece as part of an ecocritical tradition that challenges typical historiographical emphases on urban, cosmopolitan, technologized modernism.

\section{Machinism or Pastoralism?}

While I am not the first to receive Machines agricoles in terms of its pastoral associations, others have typically done so only in passing. For example, Martin Cooper has acknowledged the "strong pastoral vein" that runs throughout Milhaud's music but does not dwell on the relevance of that vein to this particular piece. ${ }^{27}$ Similarly, James Harding has noted the "rustic mood" in "La moissonneuse Espigadora" but does not elaborate. ${ }^{28}$ With a title and texts that seem to glorify machines far more than the land or its laborers, Machines agricoles has invited far more analysis of its "mechanical" qualities. Milhaud himself compounded the problem with his statement (already quoted above) that the "spirit that brought [Machines agricoles] to life was similar to the one that motivated ... Honegger to glorify a locomotive and Fernand Léger to exalt machines." ${ }^{29}$ Milhaud scholar Barbara Kelly has cautioned against interpreting Machines agricoles as a Futurist work, but does not deny the work's focus on machines. ${ }^{30}$ And the only extensive analysis of the piece to date-by theorist Deborah Mawer-focuses exclusively on the work's "outrageously 'mechanistic" qualities. ${ }^{31}$

Mawer has argued that Machines agricoles provides "the most obvious illustration" of Milhaud's "great fascination with, and respect for, mechanisms" in his works from the late 1910s and early 1920s. ${ }^{32}$ For instance, regarding the third song of the set, "La Lieuse," Mawer describes doubled piccolo and bassoon lines four octaves apart as "a crazy set of gears, or cogs, running in parallel." 33 Yet similar doubling occurs in other pieces written around the same time, none of which betray any explicit connection to machinery. For example, in the third movement of Milhaud's Second Chamber Symphony (1918), the

\footnotetext{
${ }^{26}$ On connections between politically conservative evocations of rural France and French folklore in interwar music, see Jane Fulcher, "Musical Style, Meaning, and Politics in France on the Eve of the Second World War," Journal of Musicology 13, no. 4 (Autumn 1995): 425-53. Elsewhere, Fulcher nevertheless acknowledges that political affiliations among members of Les Six remained somewhat fluid in the late 1910s and early 1920s, but that they "were still cognizant of ... cultural questions and addressed them in their works not only through stylistic oppositions but through choices of collaborators and texts" (The Composer as Intellectual: Music and Ideology in France 1914-1940 [New York: Oxford University Press, 2005], 172). Machines agricoles offers one opportunity to understand Milhaud's intellectual and political beliefs through the politically infused subtext of ruralism.

${ }^{27}$ Martin Cooper, French Music from the Death of Berlioz to the Death of Fauré(London: Oxford University Press, 1951), 190.

${ }^{28}$ James Harding, The Ox on the Roof: Scenes from musical life in Paris in the Twenties (New York: St. Martin's Press, 1972), 90.

${ }^{29}$ Milhaud, Ma Vie heureuse, 105.

${ }^{30}$ Barbara Kelly, Tradition and Style, 139. According to Kelly, the work merely "reveals [Milhaud's] desire to imbue musical life into unlikely objects rather than any commitment to the Futurist movement."

${ }^{31}$ Mawer, Darius Milhaud, 87.

32 Ibid., 101.

${ }^{33}$ Ibid., 89.
} 
violin and double bass double each other at a distance of three octaves. Milhaud employs the same doubling with the piccolo and bass clarinet in L'Homme et son désir (1917-1920), and with the violin and bassoon in the second movement of the Third Chamber Symphony (1921). Echoing Mawer, Roger Nichols asserts that "agricultural machinery implied dense textures" to Milhaud. ${ }^{34}$ Yet the texture in Machines agricoles is no denser than in other chamber works of the period. It seems more likely, then, that in the late 1910s Milhaud considered timbre and texture to be venues for experimentation along with harmonic language and instrumentation. Rather than signaling mechanical devices, the doublings and dense textures in Machines agricoles correspond to Milhaud's search for unusual timbres that distinguish melodies within contrapuntal thickets. While Mawer and Nichols understand similarities between the chamber symphonies and Machines agricoles as evidence that Milhaud generally practiced "mechanistic" composition, resemblances between the works might just as easily connote pastoral concerns.

Blinded by the superficial reference to machines in its title, critics have ignored the fact that Machines agricoles emerged during a burst of composition demonstrating Milhaud's interest in pastoralism and the natural world. Milhaud acknowledged in his autobiography that Machines agricoles was written "in the style of the little symphonies," evidence for which can be found in self-quotation and in related or outright shared subtitles. ${ }^{35}$ The third movement of the Second Chamber Symphony and the second movement of Machines agricoles both feature prominently the same melodic figure in the oboe (second staff from the top, Figure 1) and violin (fourth staff from the bottom, Figure 2).

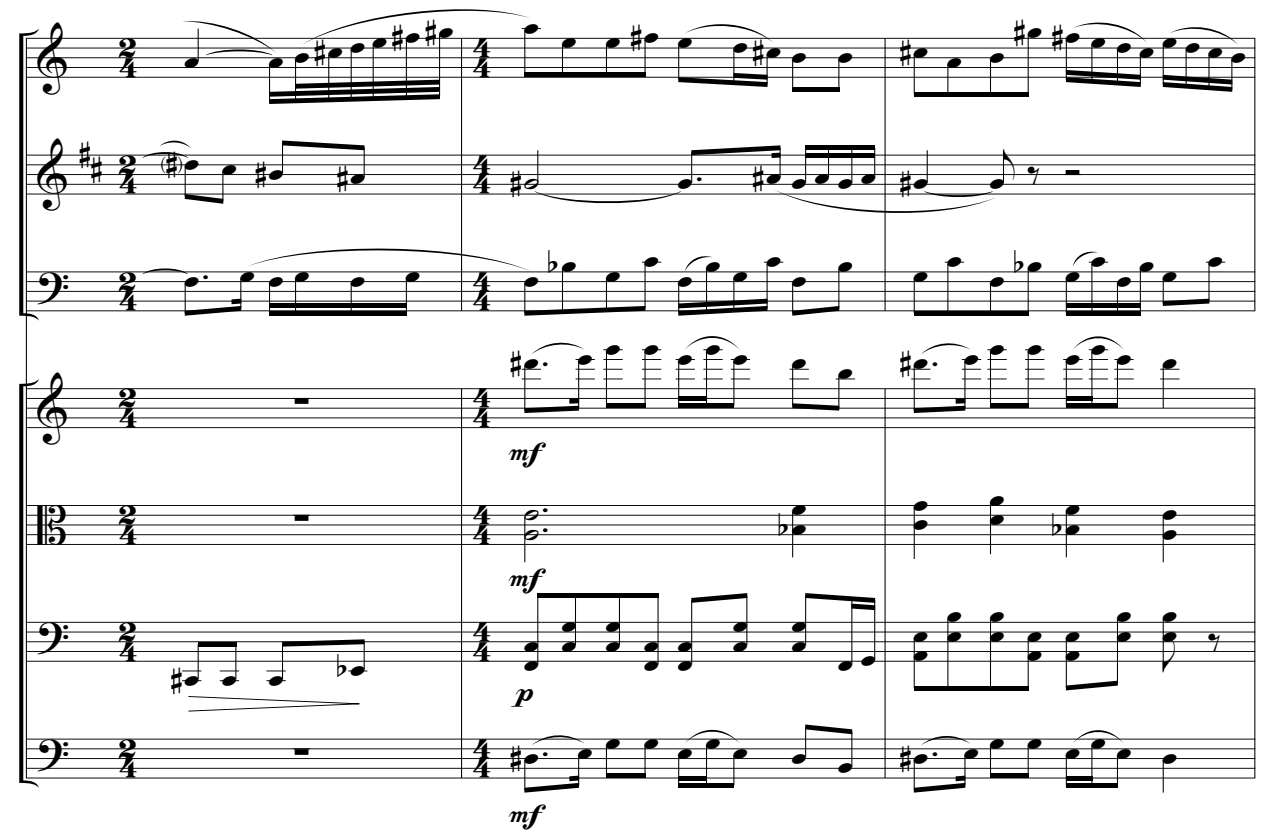

Figure 1: Chamber Symphony No. 2, mvt. iii, mm. 4-6 $6^{36}$

2. Symphonie|Pastorale | für kleines Orchester|op. 49

(C) Copyright 1922 by Universal Edition A.G., Wien.

Copyright renewed 1950 by Universal Edition A.G., Wien/UE 7192B

\footnotetext{
${ }^{34}$ Nichols, The Harlequin Years, 238.

${ }^{35}$ Milhaud, Ma Vie heureuse, 105. “... je fis alors une petite suite pour chant et sept instruments solistes dans le style de mes petites symphonies..."

${ }^{36}$ Darius Milhaud, Petite Symphonie No. 2(Vienna: Universal Edition, 1925), 14.
} 


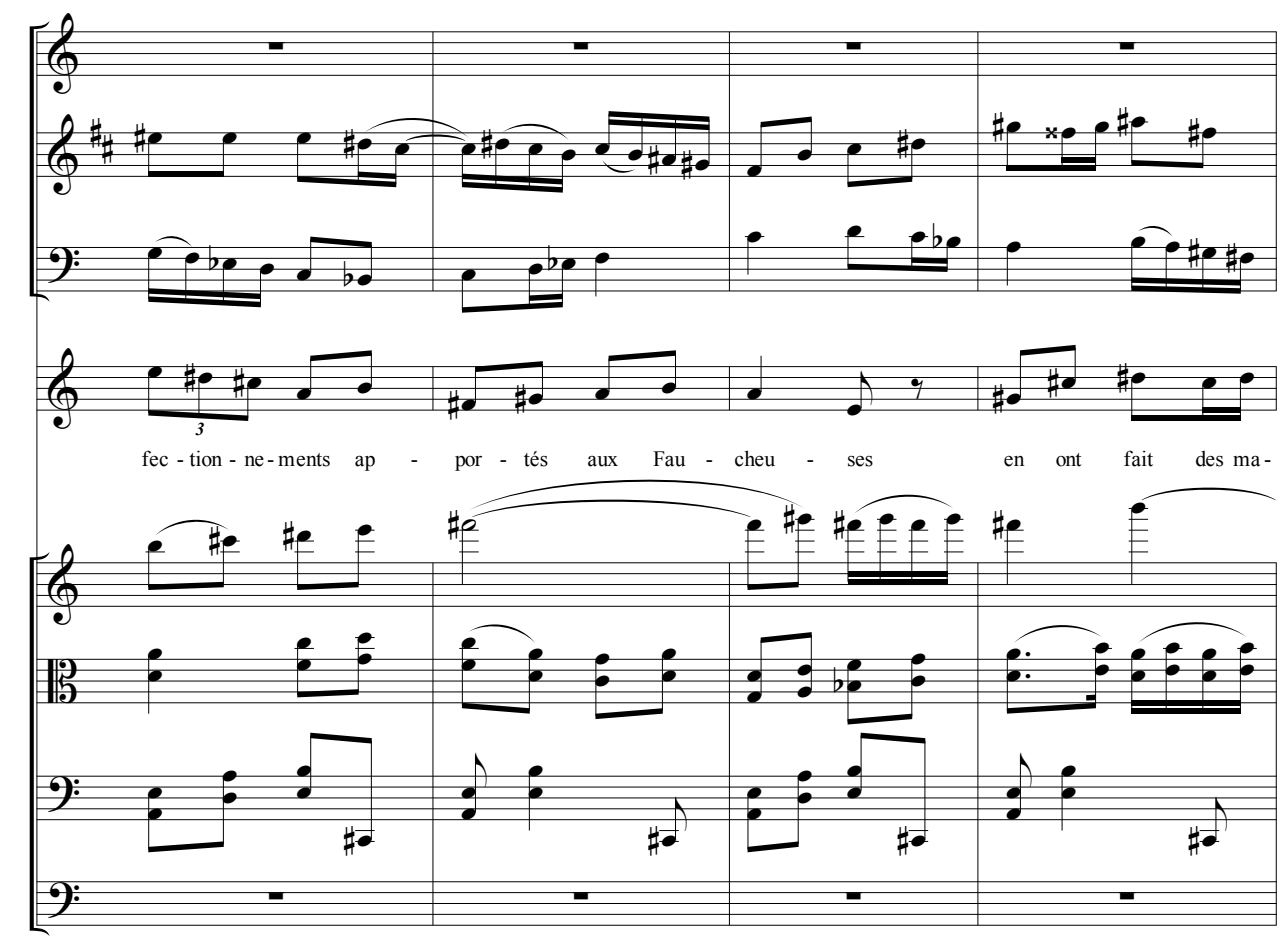

Figure 2: Machines agricoles, "La Faucheuse," mm. 4-7 $7^{37}$

Machines agricoles 6 pastorale Gesänge | für mittlere Stimme, Flöte, Klarinette, Fagott, Violine, Viola, Violoncello und Kontrabass|op. 56

(C) Copyright 1926 by Universal Edition A.G., Wien/UE 8142

The accompaniment for these figures is also remarkably similar in the two movements, with cello-viola pairs moving in double-stopped, parallel fifths. ${ }^{38}$ Milhaud uses this figure again in the fifth movement of Machines agricoles, "La Fouilleuse-draineuse," but without the double-stop accompaniment. In addition to sharing musical material, the chamber symphonies and Machines agricoles share sources of inspiration in the natural world. To his first chamber symphony, composed in 1917, Milhaud appended the subtitle "Printemps," perhaps a tongue-in-cheek reference to the eponymous 1887 symphonic work by Debussy. Its instrumentation is remarkably similar to that for Machines agricoles: both pieces feature flute, clarinet, violin, viola, and cello; where the chamber symphony adds piccolo, oboe, harp, and a second violin, Machines agricoles adds voice, bassoon, and double bass. Composed in 1918, Milhaud's second chamber symphony—the one with the closest links to Machines agricoles—received the subtitle "Pastorale." Unlike Machines agricoles, this earlier pastorale includes numerous melodies inspired by folk song. In particular, the second movement of the chamber symphony features a lengthy oboe solo reminiscent of the pastoral scene in the third movement of Berlioz's Symphonie fantastique. Milhaud dedicated the Petite symphonie No. 2 to "roseau et pipeau"-reed and reed pipe. If there were any extramusical association for the melodic doubling, the double-stopped parallel fifths, or the generally dense textures in Machines agricoles, then the precedent set by the chamber symphonies should point to the natural and the bucolic rather than the mechanical.

Beyond relationships between Machines agricoles and the pastorally oriented, early chamber symphonies, Milhaud's "mechanistic" song cycle fails to match the sonic fervor for modern technology

\footnotetext{
${ }^{37}$ Milhaud, Machines agricoles, 9.

${ }^{38}$ Kelly, Tradition and Style, 159.
} 
present in the other examples of later machine-inspired music with which Mawer aligns it: Arthur Honegger's Pacific 231 (1923), George Antheil's Airplane Sonata and Ballet mécanique (1925), Paul Hindemith's unpublished Musik für mecanische Instrumente (1926), Alexander Mossolov's The Iron Foundry (1927), and Maurice Ravel's Boléro (1928). ${ }^{39}$ The beginning of Pacific 231 provides an apt example, and significantly, it was the piece to which Milhaud referred in his autobiography when he described Honegger's effort to "glorify a locomotive." In the work, Honegger deliberately evokes a train's lumbering acceleration. ${ }^{40}$

Example 2: Honegger's Pacific 231, excerpt.

Listen at: http://dx.doi.org/10.3998/mp.9460447.0008.204

Honegger's emphasis on the metallic sonorities of the low brass and regular pulse of the strings through the first third of the piece make explicit the composer's source material. Similarly, the obsessive repetition of Ravel's Boléro links it clearly to the factory setting that Ravel acknowledged as his inspiration. ${ }^{41}$ If there are mechanical "devices" in Machines agricoles, Milhaud includes far fewer than are easily found in other machine-inspired pieces. The ostinato that pervades Machines agricoles could be understood as a machine-like, repetitive impulse, but it might be more productive to consider in terms of Stravinsky's ostinati in Le Sacre du Printemps. After all, Stravinsky's heavy reliance on repetitive gestures in that work found inspiration in the rituals of the pagan Russians depicted in the original ballet-rituals intended to ensure a rich agricultural bounty. Ultimately, futurism seems an unlikely source of inspiration for Milhaud. When he referenced Léger and Honegger in his autobiography, he did not mean to compare his own treatment of machines with that of his peers. Rather, he was merely noting that his choice of subject had illustrious, contemporary analogs that had suffered far less criticism.

If Milhaud references machines at all in his music, they are not of the same genus as those conjured by Honegger, Antheil, Ravel, or Prokofiev. ${ }^{42}$ For one thing, Milhaud's machines relied on human and animal power to operate, unlike the largely automated trains, planes, and factories evoked by the music of his peers. Milhaud's machines do not emit the sounds that will inspire the music of the future, sounds of speed over long distance or of systematic, synthetic production. Rather, they transmit the sounds of fields and farmwork circa 1913. And the sounds of even these machines are faint at best-perhaps a nod to the increasingly straitened circumstances of farm workers in the years between 1913, when Milhaud picked up farm machinery catalogues at a trade show, and 1919, when he set them to music.

\footnotetext{
${ }^{39}$ Mawer, Darius Milhaud, 101-2. To Mawer's list we might add Prokofiev's Pas d'Acier (1928) among the pieces in which the spirit and sounds of technology inspire not just melodic material but also texture, contour, and form.

${ }^{40}$ See Harry Halbreich, Arthur Honegger, trans. Reinhard G. Pauly (Portland: Amadeus Press, 1999), 351.

${ }^{41}$ For a thorough examination of the connections between form, motive, and orchestration in Boléro and the factory setting Ravel initially envisioned for the ballet, see Deborah Mawer, "Ballet and the Apotheosis of the Dance," in The Cambridge Companion to Ravel, ed. Deborah Mawer (Cambridge: Cambridge University Press, 2000), 155-61.

${ }^{42}$ For a discussion of music written around the same time as Machines agricoles that more pointedly engages with machine aesthetics, see Glenn Watkins, Pyramids at the Louvre: Music, Culture, and Collage from Stravinsky to the Postmodernists (Cambridge, MA: Harvard University Press, 1994), 322-41.
} 


\section{Rural Life and Representation in Early Twentieth-Century France}

Unlike many of his Paris-based colleagues and acquaintances, Milhaud had reason to be particularly attuned to the plight of peasants and traditional, rural ways of life. Though he grew up in the city-center of Aix-en-Provence, his father was an almond dealer whose business brought the entire family into contact with farmers. In his autobiography, Milhaud recalled being immersed in the sounds of agriculture from a young age. ${ }^{43}$ The Milhaud family also owned an estate outside the city, L'Enclos, to which the composer continued to sojourn yearly well into adulthood. At L'Enclos Milhaud watched villagers send their livestock into the mountains, experiencing the "uninterrupted waves of bleating sheep whose noise blended with the normal sounds" of the working farm on the estate. ${ }^{44} \mathrm{He}$ also described the cacophony of birds, frogs, and crickets that filled the air after sundown. While Les Six are famous for their urban flânerie-their visits to popular fairgrounds outside of Paris and slum-chic bars within the city limitsMilhaud stands apart for his earnest interest in rural culture. For instance, rather than finding the farm machine catalogue in a used book store in Paris (as Poulenc had found his texts for Rapsodie nègre), Milhaud's acquisition of a farm machine catalogue took place when he attended a farm show with friends who needed to buy a new mower for their own farm. ${ }^{45}$ The composer, then, was in a position to be conscious of (and perhaps touched by) the increasingly difficult circumstances experienced by peasants and farmers.

Even without a biographical link to rural culture, Milhaud could not have avoided ruralist discourses in the years leading up to and immediately following the First World War. The politics of rural life first began registering in the public consciousness of urban France around the advent of the Third Republic in 1870 , only accelerating with the completion in the 1880s of a secondary railroad network that ended the isolation of many rural areas. In the early 1890s the number of French farms started decreasing for the first time since the Revolution, a shift prompted by two stimuli: increased competition in international wheat export markets and an infestation of phylloxera that destroyed much of the nation's vineyards. As competition and infestation made farming less profitable, the economy of the industrial revolution enticed farmers away from their fields through the promise of steady work in urban areas. The flow of peasants from rural areas to cities incited politicians to condemn the consolidation of many small farms into fewer large estates, but the government could do nothing to stop a decrease of six hundred thousand farms between 1892 and 1929. ${ }^{46}$ In general, the state failed to enact policies that eased the heavy economic burden felt by poorly educated peasants and farmers, who generally did not represent themselves in government. With low birth rates and mass migration from rural to urban areas, France's rural population steadily declined over four decades from approximately two thirds of the total population in the 1890s to only one third in 1930, with the tipping point right around $1920 .^{47}$

\footnotetext{
${ }^{43}$ Milhaud, Ma Vie heureuse, 15.

${ }^{44}$ Ibid., 16. “. . . déferlement ininterrompu de bêlements qui se mêlaient aux bruits habituels de l'Enclos.”

45 Ibid., 104.

46 These figures and many others on French rural life between 1870 and 1940 are available in Gordon Wright, Rural Revolution in France: The Peasantry in the Twentieth Century(Stanford: Stanford University Press, 1964), 14-32; Eugen Weber, The Hollow Years: France in the 1930s (New York: W. W. Norton \& Company, 1994), 37-41; Michel Gervais, Marcel Jollivet, and Yves Tavernier, La Fin de la France paysanne, Vol 4. of Histoire de la France rurale, eds. Georges Duby and Armand Wallon (Paris: Éditions du Seuil, 1977), 10-64; and Geneviève Gavignaud, Les Campagnes en France au XXe siècle (1914-1989)(Paris: Éditions Ophrys, 1990).

${ }^{47}$ Romy Golan, Modernity and Nostalgia: Art and Politics in France between the Wars (New Haven, CT: Yale University
} 
The First World War accelerated changes to rural life, triggering profound and widespread anxiety over disappearing traditions and a reduced workforce. In the immediate postwar period, with 1.4 million dead and another 1.1 million left permanently disabled, twenty percent of France's male population disappeared from the work force. ${ }^{48}$ Of these millions, around half-more than 650,000 of the dead and 500,000 of the disabled-were classified as "peasants," defined in terms of rural residency and low social class. ${ }^{49}$ Thus the nation suffered the necessity of increased reliance on machines agricoles, both to replace the dead and assist the wounded. One newspaper article from June 1919 described efforts sponsored by the Ministry of Agriculture to develop prosthetics and farm machinery geared toward "those injured [mutiles] in the war." 50 The goal of the Ministry of Agriculture was "to permit them to continue to practice their vocation as farmers." 51 Efforts to supplement the existing rural work force reflected the fact that replacing and reconditioning farm workers took years. While machines could stand in for some farm workers, each machine still required numerous hands to operate. According to one report, in 1925 a thresher could harvest 120 hectoliters of wheat in a day with the help of no fewer than twelve farmworkers. As a farm mechanic somberly noted in response to these figures,

How many scythes and how much time does it take to obtain this result? As there are no longer enough workers, the yield per hectare that makes farm machines cost-effective is only a matter of historical interest . . Even if you only had one hectare of pasture or of grains to mow, you have to use a machine to ensure that the work gets done at the right moment. ${ }^{52}$

Ultimately, the war rendered moot the question of whether to use a machine or human hands. Farm machines increasingly became a necessity of rural life.

The impact of the First World War on agricultural production had already become an issue of national importance even before the end of the war. Wartime propaganda played on the longstanding link between terroir and patrie by juxtaposing imagery of manual farm labor with symbols of the nation. For instance, in a 1918 poster soliciting support for a war bond campaign (Figure 3), a bucolic landscape in earth tones depicts farm workers bundling hay in a field. Notably, the workers are all women and children rather than men. ${ }^{53}$ The clouds above the workers take the form of Marianne exhorting massed armies on to battle. Thus the artist casts the male, peasant farmworkers cum martyred soldiers as a timeless presence, ubiquitous and intangible as clouds rolling over open fields. In another war bond campaign ad from 1920 (Figure 4), a man plowing behind two oxen doffs his cap as he passes a cross decorated with ribbons and

\footnotetext{
Press, 1995), 50.

${ }^{48}$ Eugen Weber, The Hollow Years, 11.

${ }^{49}$ Wright, Rural Revolution, 28-29.

50 “Appareils de prothèse et machines agricoles pour mutilés de la guerre," La Lanterne, June 17, 1919, accessed via gallica.bnf.fr, 23 November 2013. “. . . le minister de l'Agriculture et du Ravitaillement a decidé d'organiser en 1919 des essais et demonstrations pratiques d'appareils de prothèse et de machines agricoles destines aux mutilés de la guerre, pour leur permettre de continuer pratiquement à exercer leur métier d'agriculteur.”

${ }^{51}$ Ibid.

52 J.H. Sourisseau, Le Développement du machinisme en agriculture (Toulouse, Imprimerie régionale, 1926), 1, quoted in La Fin de la France paysanne, 59-60. “Combien de fléaux et combien de temps faudrait-il pour obtenir ce résultat? Puisqu'il n'y a plus d'ouvriers en nombre suffisant, le rapport au nombre d'hectares qui fixe le seuil de rentabilité des machines n'a plus qu'un intérêt historique ... N'aurait-on qu'un hectare de prairies ou de céréales à couper, il faut utilizer la machine si on veut que le travail soit fait au moment qui convient."

${ }^{53}$ Romy Golan has noted that the overwhelmingly female subjects of postwar, farming-themed advertisements combined the symbolism of feminine fertility with agricultural fecundity to emphasize the regenerative powers of the land. See Golan, Modernity and Nostalgia, 18.
} 
flowers. The implication is clear: for every man who returned from the front to work the land, another did not.

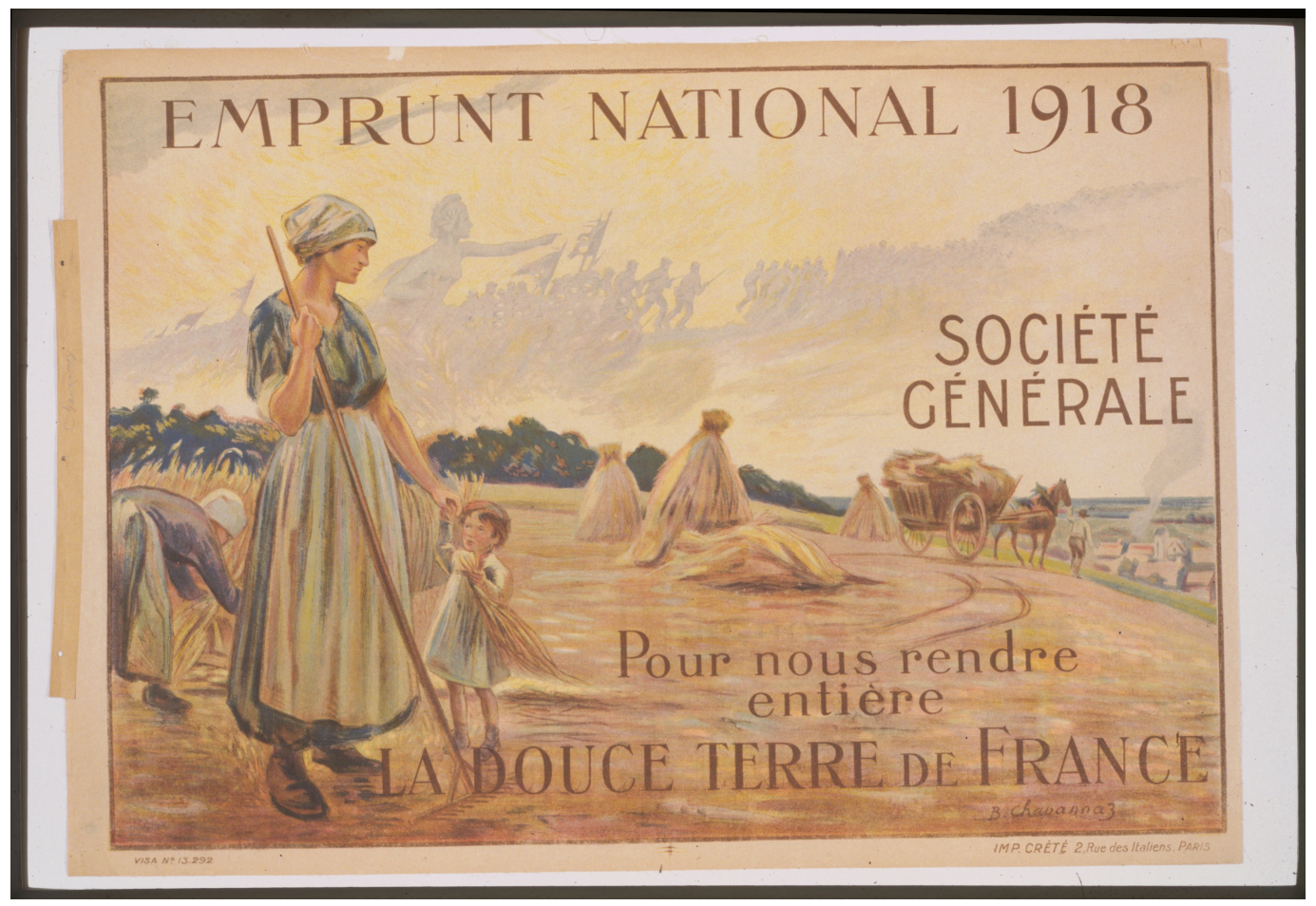

Figure 3: "National Loans 1918 - To return to us whole the sweet land of France."54

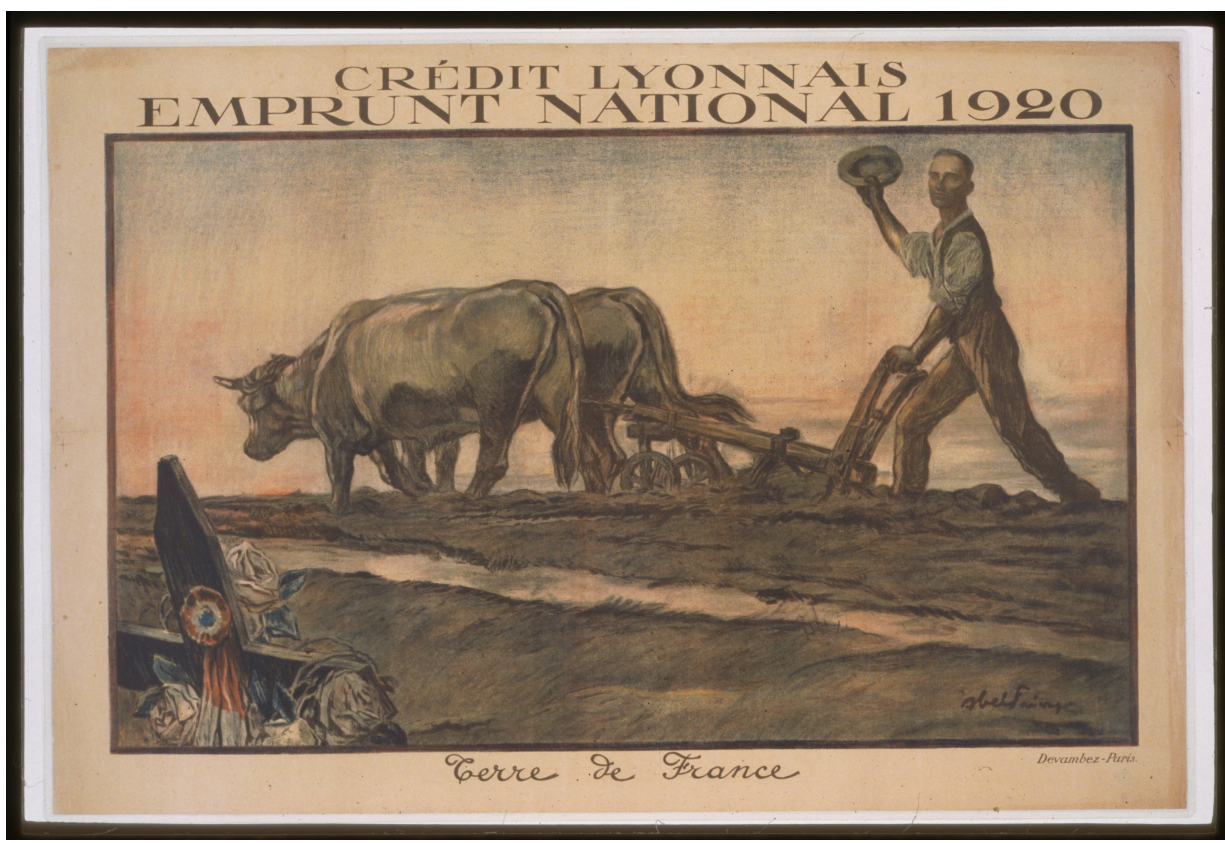

Figure 4: "National Loans 1920 - French earth"55

\footnotetext{
${ }^{54}$ B. Chavannaz, "Emprunt National 1918," Prints and Photographs Division, Library of Congress, accessed October 10, 2013, http://www.loc.gov/pictures/item/99613673/.

${ }_{55}$ Abel Faivre, "Emprunt National 1920. Terre de France," Prints and Photographs Division, Library of Congress, accessed October 10, 2013, http://www.loc.gov/pictures/item/99613775/.
} 
Not only did peasant-soldiers bear the brunt of fighting and dying in the First World War, but they were also made responsible for healing the nation's wounds through cultivation. In his 1921 book Trésors d'art de la France meurtrie, author Marcel Aubert argued, "Surely, nature will soon hide with its endless regenerative powers the murder attempts and the crimes of men. Filled in, the trenches will disappear under the plow." ${ }^{56}$ Notably, Aubert cast the machine-facilitated work of farmers as a "natural" form of regeneration.

War bond ads romanticized peasant life, reflecting a traditional escapist tendency in urban fantasies of rural spaces. Despite officials' desire to celebrate the contribution of the peasant-soldier, however, such images ultimately obscured the economic and social plight of rural inhabitants. Around the same time that the return of peasant farm cultivation was touted as the healer of war wounds, new industrial methods imported from the United States posed a new threat to traditional farming techniques and to the employment prospects for workers in both urban and rural areas. Taylorism and Fordism originally sought to increase the efficiency of industrial production through specialization and assembly-line manufacturing, but farmers in the United States had already begun applying their principles to agriculture, and French estate owners began following suit in the late 1920s. As French Studies scholar Shanny Peer has noted, the new emphasis on industrial production during and immediately following the war was "widely viewed as a threat to traditional, local cultures and to artisanal modes of production," not least agricultural production. $^{57}$

In the face of rapid technological change, even the 1913 models of farm machines featured in Milhaud's catalogue must have seemed quaint. Milhaud's aestheticization of these machines may have been motivated by an escapist fantasy in which the destructive, motorized machinery of the wartime and immediate postwar landscape never existed. For instance, the catalogues Milhaud used describe premotorized farm machinery: the harvester of the first movement reaps "twelve to fifteen hectares per day"- a low number by the standards of even a decade later. ${ }^{58}$ The mower of the second movement is pulled "by one or two horses," and it is safe to assume the other machines, too, required animal power. ${ }^{59}$ Although the word "machine" implies automation today, much of the machinery described in Machines agricoles still demanded the participation of numerous farmhands to operate (Figure 5).

\section{Machines agricoles as Post-Pastoral}

In Milhaud's song cycle, these already obsolete farm machines became nostalgic markers of a time when machines were more like insects and farms were less like factories, when harvesting twelve to fifteen hectares per day was considered the height of productivity. But rather than dwelling in nostalgia or romanticizing the plight of the peasant farmer, Milhaud's setting of texts from farm machinery catalogues emphasizes the tensions between conflicting visions for the rural landscape in the immediate postwar era.

\footnotetext{
${ }^{56}$ Marcel Aubert, Trésors d'art de la France meurtrie (Paris: Gazette des Beaux Arts, 1921), 7, quoted and translated in Golan, Modernity and Nostalgia, 41. "Sans doute la nature aura vite fait de cacher sous la poussée de ses forces éternellement créatrices les attentats et les crimes des homes; les tranchées comblées disparaîtront sous les sillons nouveaux."

57 Shanny Peer, France on Display: Peasants, Provincials, and Folklore in the 1937 Paris World's Fair (Albany: State University of New York Press, 1998), 11. Peer demonstrates that anxieties over the loss of traditional rural life in France motivated the organizers of the 1937 Paris Expo to increase the visibility of rural and provincial French culture at the fair.

${ }^{58}$ Milhaud, Machines agricoles, 5.

59 Ibid., 11.
} 


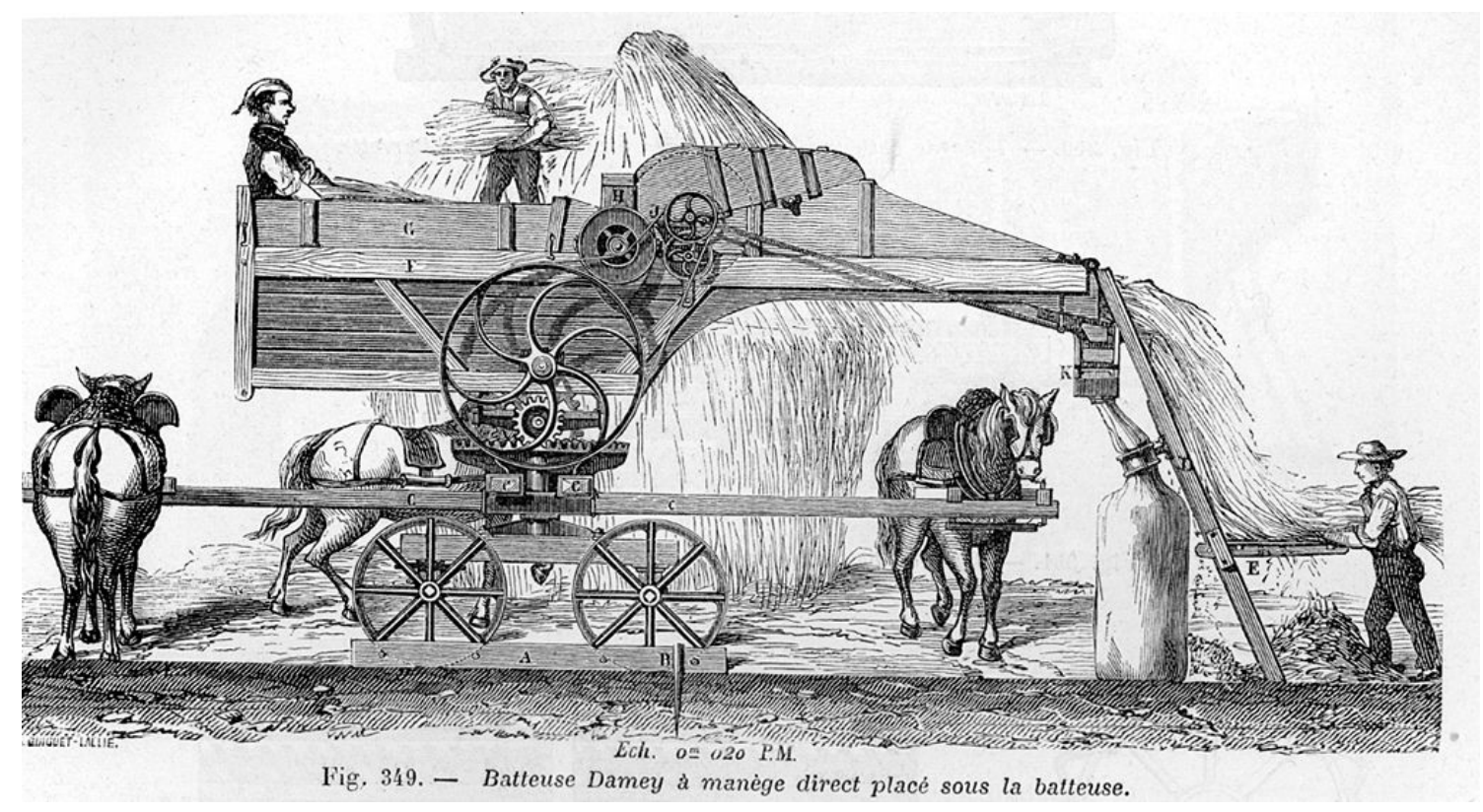

Figure 5: "Damey Thresher operated via carousel placed under the thresher."

In opposition to the escapist pastoralism of Debussy and Ravel, whose music offered refuge from the anxiety-laden present by conjuring idyllic, imagined pasts, in Machines agricoles Milhaud pursued a more critical stance, authoring an example of a post-pastoral, thus both perpetuating and problematizing the pastoral genre. $^{61}$

Milhaud could have chosen any number of models for his contribution to the pastoral genre. Given that he had chosen to write a (chamber) symphony, he might have looked toward famous works such as Beethoven's Symphony No. 6, "Pastoral," Brahms's Symphony No. 2, and Mahler's Symphony No. $3{ }^{62}$ But to do so would have clashed with Milhaud's priorities: avoiding Austro-German antecedents and updating (rather than merely perpetuating) musical pastoralism. Of course, as was the case for a great deal of twentieth-century music, Milhaud bypassed the recent past in favor of an older model. In his autobiography, Milhaud claimed a pastoral pedigree among composers who "sang the praises of the field harvest [les moissons], the grape harvest [le vendange], the 'good farmer." "63 His most likely reference was to François Couperin, whose keyboard piece "Les Moissonneurs" from the Second livre de pièces de Clavecin (1717) uses rustic, simple melodies and open voicings to evoke wholesome peasant fun.

\footnotetext{
${ }^{60}$ Eugène-Oscar Lami and Alfred Tharel, eds., Dictionnaire encyclopédique et biographique de l'industrie et des arts industriels Vol. 1, A-B (Paris: Lami, Tharel \& Cie., 1881-1891), accessed October 10, 2013, http://gallica.bnf.fr/ark:/12148/bpt6k39779z.image.f596.pagination. Another example of the machines agricoles common in Milhaud's time can be seen at http://youtu.be/36TdYi6gvaM and http://youtu.be/-zZh9KjcWqY?t=16m35s (accessed October 10, 2013).

${ }^{61}$ Milhaud, Machines agricoles.

${ }^{62}$ Secondary literature on pastoralism in music is substantial and wide-ranging. On pastoral music in the nineteenth century, see especially Aaron Allen, "Symphonic Pastorals," Green Letters: Studies in Ecocriticism 15 (2011): 22-42; Reinhold Brinkmann, Late Idyll: The Second Symphony of Johannes Brahms, trans. Peter Palmer (Cambridge, MA: Harvard University Press, 1995); Richard Will, The Characteristic Symphony in the Age of Haydn and Beethoven (Cambridge: Cambridge University Press, 2002); Thomas Peattie, "In Search of Lost Time: Memory and Mahler's Broken Pastoral," in Mahler and His World, ed. Karen Painter (Princeton: Princeton University Press, 2002), 185-98.

${ }^{63}$ Milhaud, Machines agricoles.
} 
Example 3: François Couperin's "Les Moissonneurs” from Second livre de pièces de Clavecin (1717)

Listen at: http://dx.doi.org/10.3998/mp.9460447.0008.204

While Couperin's music idealized the rural using compositional techniques Milhaud seems to have avoided, it does so through a wide variety of musical techniques, not just through a narrow range of clichéd pastoral tropes. As we will see, Milhaud similarly set his pastoral texts with a number of techniques coded as decidedly nonpastoral.

The likely choice of "Les Moissonneurs" as a model is also significant because it signals Milhaud's interest in bypassing precedents set in more recent works by Ravel and Debussy. Consistent with his participation in the musical rappel à l'ordre championed by Jean Cocteau in Le Coq et l'harlequin, Milhaud sought to shed the baggage of Debussysme (entangled as it was in Wagnerism, which Milhaud detested) in favor of rediscovering a more lyrical, denuded aesthetic consistent with pre-nineteenthcentury French music. ${ }^{64}$ To be fair, towards the end of his life, Debussy also distanced himself from the influential style he had pioneered. His Sonata for flute, viola, and harp (1915) resembles Milhaud's stripped-down chamber music far more than it resembles Debussy's earlier works. Nevertheless, Debussy had not rejected his own sensual pastoralism enough to satisfy Milhaud. Just as the chamber symphonies marked an attempt to redirect the symphony away from late-Romantic maximalism, Machines agricoles represented an opportunity to reorient the pastoral toward the eighteenth century. In doing so he could claim a precedent in an archaic pastoral mode that focused on contemporaneous rural life rather than an imagined rural past. Milhaud joined Couperin in singing the praises of cultivation and the harvest. But with a text about machines, Milhaud's pastoral updated the genre to encompass new, ubiquitous elements of the rural landscape. That these elements were man-made and contributed to the creation of a constructed environment rather than a "natural" one recommends the application of Gifford's label "postpastoral" to Milhaud's idiosyncratic appropriation of catalogue texts in Machines agricoles.

The post-pastoral label applies equally well to Milhaud's music. Rather than rejecting pastoral conventions entirely, Milhaud sprinkled throughout the piece a number of existing pastoral tropes, most of which have gone unnoticed among all the attention to the piece's machinism. At the same time, Milhaud sought to apply a new musical language to describe new pastoral subjects, specifically farm machinery whose pastoral bona fides might be thought dubious outside of the context of the rural crisis gripping France in the early twentieth century. An example of a reference to existing pastoral norms accompanied by novel techniques can be found at the piece's beginning. The first movement opens with two simultaneous pentatonic lines, one played by the viola and composed of the collection $\mathrm{Bb}-\mathrm{C}-\mathrm{Eb}-\mathrm{F}-\mathrm{G}$, the other in the clarinet and composed of the collection C-D-E-G-A (Figure 6). After two measures, the two instruments switch collections for the next two measures. Only with the introduction of the voice in measure 5 does the exclusively pentatonic nature of the piece give way to more freely polytonal texture, and even then the cello remains in a $\mathrm{C}$ pentatonic mode for its first four measures.

\footnotetext{
${ }^{64}$ Richard Taruskin has famously referred to the musical interests of early twentieth-century French neoclassicists as an "end

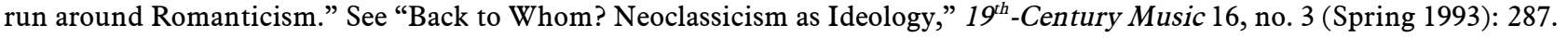




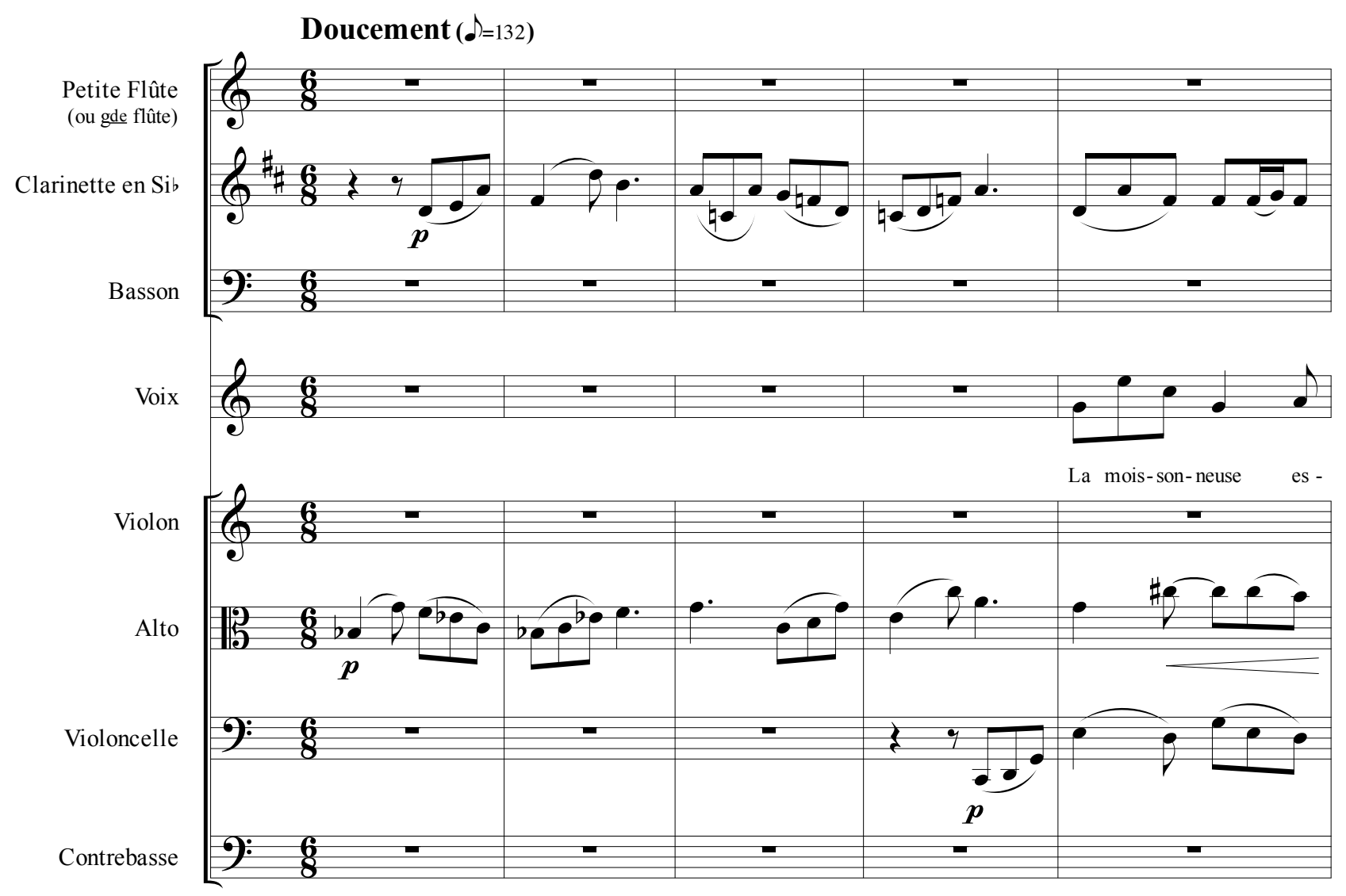

Figure 6: Machines agricoles, mvt. 1 "La Moissonneuse Espigadora," mm. 1-5 Machines agricoles|6 pastorale Gesänge| für mittlere Stimme, Flöte, Klarinette, Fagott, Violine, Viola, Violoncello und Kontrabass|op. 56

(C) Copyright 1926 by Universal Edition A.G., Wien/UE 8142

Milhaud opens the piece with a swiftly fading echo of the pervasive, pentatonic language in recent, escapist pastorals such as Debussy's Prélude à l'après-midi d'un faun and Ravel's Daphnis et Chlöé. Yet by superimposing pentatonic collections one whole step apart, Milhaud thoroughly conceals the music's allusive potential. Dissonances multiply quickly: the concert $\mathrm{D}$ in the clarinet against the Eb in the viola on the penultimate eighth note of the first measure; the awkwardly approached and nonresolving tritone (BbE) on the first eighth of the second measure; another $\mathrm{Eb}$ against $\mathrm{D}$ on the penultimate eighth note of the third measure; and still more after the cello and voice enter in measures four and five. Milhaud's purpose is not to show how skillfully he can integrate existing pastoral models into new ones, but rather (in typical modernist fashion) to create new compositional conventions by superimposing and therefore obscuring older conventions.

Recent French composers were by no means the only bearers of the pastoral tradition to undergo critical, obscurantist treatment. Early in the first movement of Machines agricoles, an ostinato composed of juxtaposed, arpeggiated second-inversion chords in $\mathrm{Eb}$ major and $\mathrm{C}$ major in the viola and cello respectively (Figure 7) echoes one of the most prominent recurring motives in the fifth movement of Beethoven's Symphony No. 6, "Pastoral” (Figure 8).

${ }^{65}$ Milhaud, Machines agricoles, 3. 

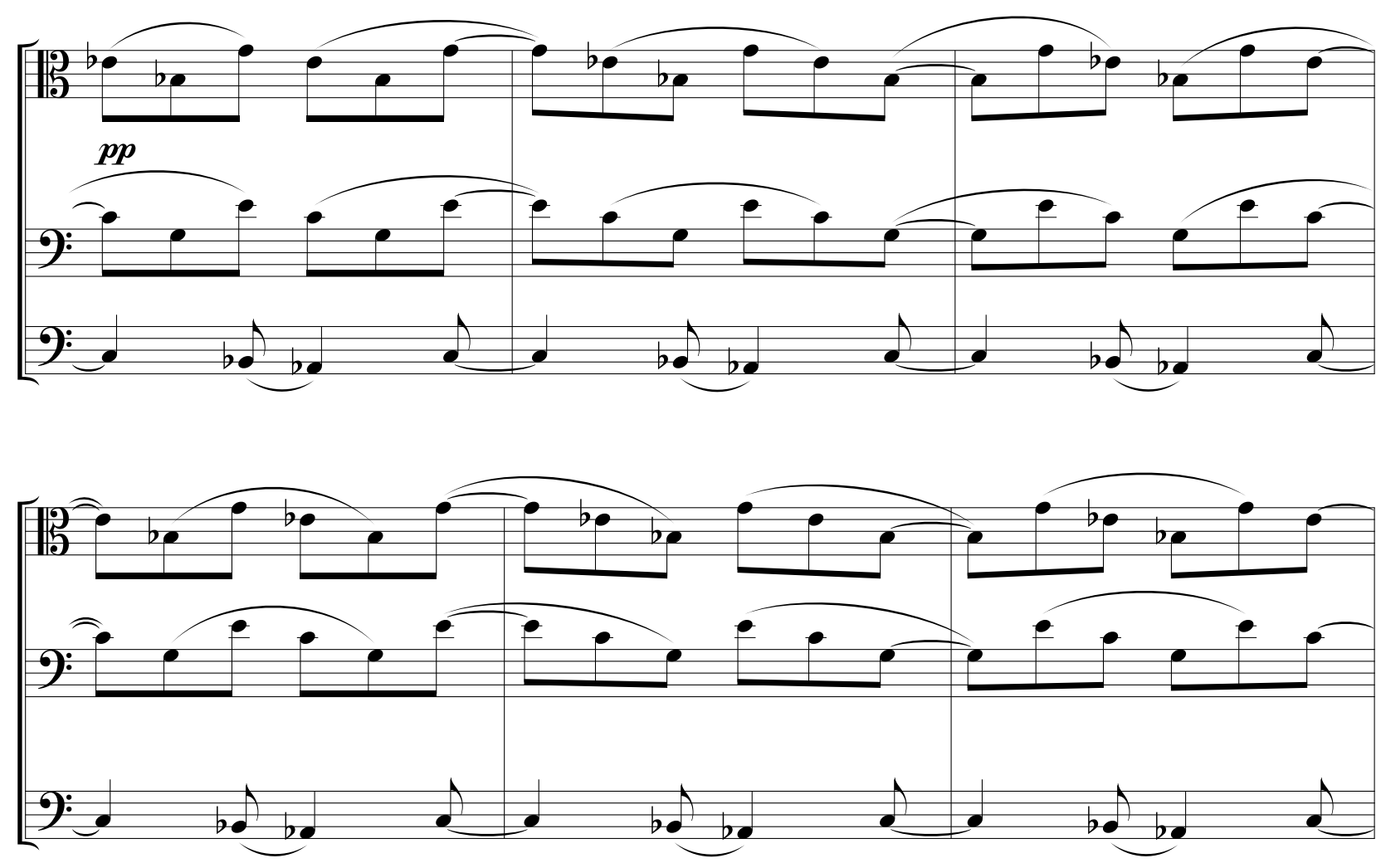

Figure 7: Machines agricoles, mvt. 1 "La Moissonneuse Espigadora," mm. 9-2066

Machines agricoles|6 pastorale Gesänge| für mittlere Stimme, Flöte, Klarinette, Fagott, Violine, Viola, Violoncello und Kontrabass |op. 56

(c) Copyright 1926 by Universal Edition A.G., Wien/UE 8142

Clarinetti 1,2 in $\mathrm{B} b$

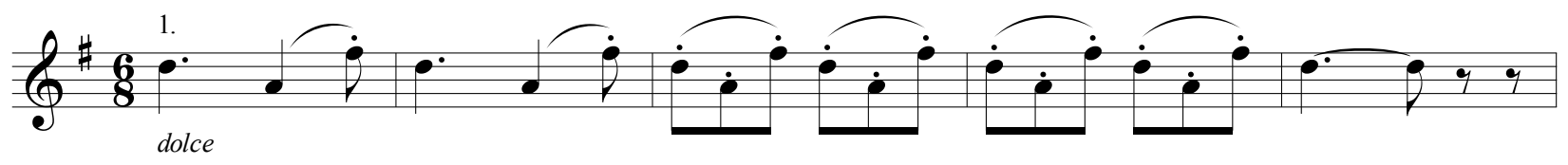

Figure 8: Beethoven, Symphony No. 6, mvt. v, mm. 1-57

In the context of three other independent lines, the reference recedes into the background, and the potentially obvious evocation of a pastoral topic recedes with it. In this manner, Milhaud cites pastoral tropes without focusing attention on them. Just like the crops and machines that appear in his texts, Milhaud's music takes on post-pastoral resonance in its seamless integration of music coded as "natural" (that is, using pastoral tropes) with music coded as "cultural," in this case Milhaud's polytonal and polyrhythmic texture.

Many other moments within Machines agricoles obscure traditional pastoral references through application of ostensibly "modernist" compositional techniques. While Milhaud shows a clear preference

\footnotetext{
${ }^{66}$ Ibid., 4-5.

${ }^{67}$ Ludwig van Beethoven, Symphony No. 6 (Palo Alto: Center for Computer Assisted Research in the Humanities, 2008), accessed November 25, 2013, http://imslp.org/wiki/Special:ReverseLookup/28605.
} 
for the stereotypical $3 / 4$ and $6 / 8$ time signatures of the pastoral, his penchant for polyrhythm (especially three sixteenths in one part against two or four in another) ensures the absence of anything resembling a folk dance feel. One of the few moments of metrical regularity comes at the end of the first movement, when a sighing, pianissimo ostinato in the strings reinforces a sense of stasis rather than mechanistic motion. The ostinato is composed of steady oscillation between two complexes of stacked, open fifths in the strings: A2-E3-B3-F\#4-C\#5-G\#5 to G2-D3-A3-E4-B4-F\#5 (Figure 9). Here Milhaud evokes the pedal drone that stood as a marker of rural music making while simultaneously offering a gauzy, spacious accompaniment for the suddenly tonal melody.

Example 4: Milhaud's Machines agricoles, end of first movement, "La Moissonneuse Espigadora."

Listen at: $\underline{\text { htp://dx.doi.org/10.3998/mp.9460447.0008.204 }}$

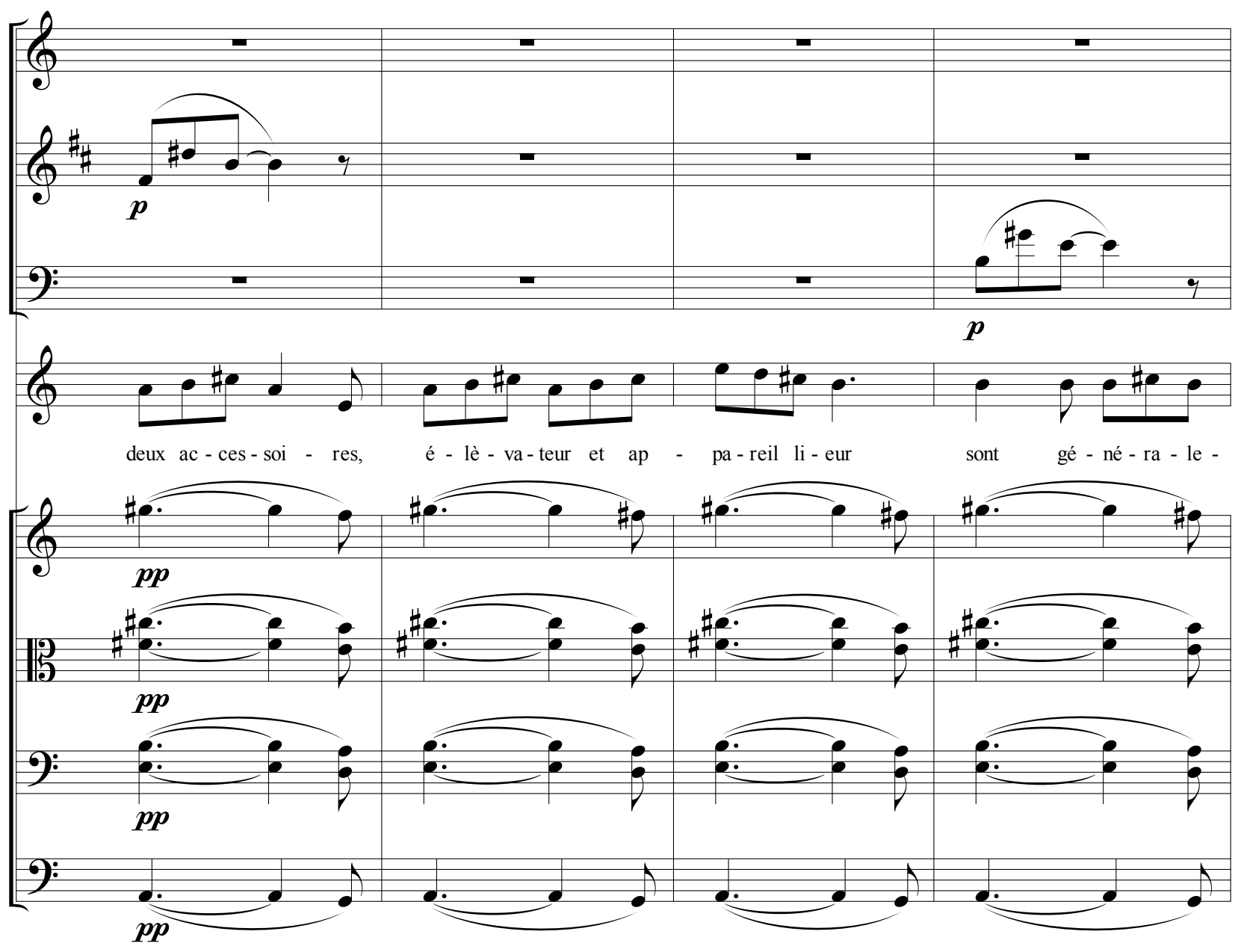

Figure 9: Machines agricoles, mvt. 1 "La Moissonneuse Espigadora," mm. 42-45 Machines agricoles 6 pastorale Gesänge | für mittlere Stimme, Flöte, Klarinette, Fagott, Violine, Viola, Violoncello und Kontrabass|op. 56

(C) Copyright 1926 by Universal Edition A.G., Wien/UE 8142

${ }^{68}$ Milhaud, Machines agricoles, 8. 
Drone harmony is even more explicit in the fifth movement, when the strings transition from pizzicato to arco and the violin and cello articulate repeated double-stopped fifths over several measures (Figure 10). Supported by the drone on F-C, the descending, pentatonic scale in the violin asserts folk spirit, particularly through its grace-note figuration.
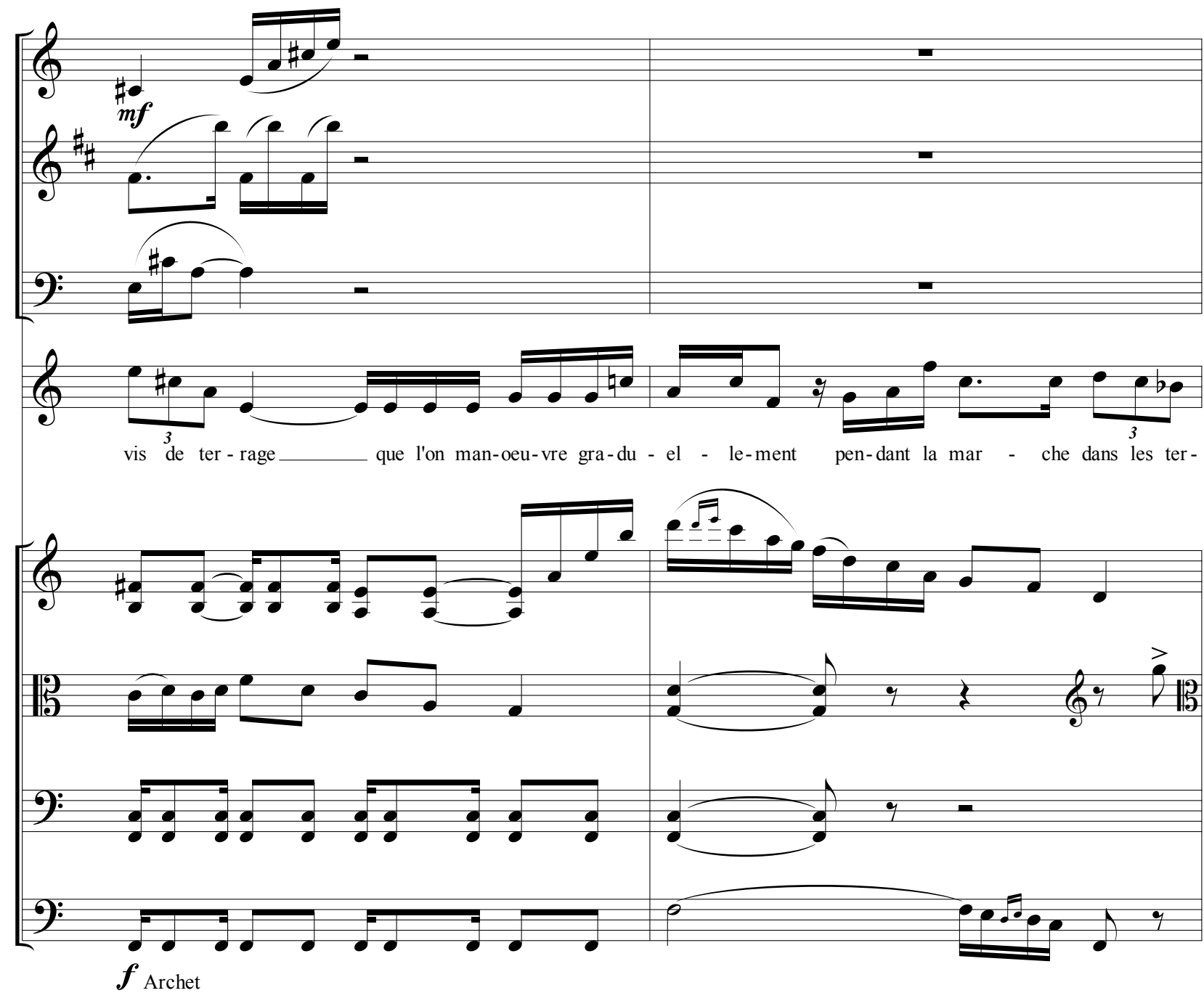

Figure 10: Machines agricoles, mvt. 5 "La Fouilleuse-Draineuse," mm. 13-14 ${ }^{69}$ Machines agricoles|6 pastorale Gesänge|für mittlere Stimme, Flöte, Klarinette, Fagott, Violine, Viola, Violoncello und Kontrabass|op. 56

(C) Copyright 1926 by Universal Edition A.G., Wien/UE 8142

Widely spaced, stacked fifths are also prevalent in the fourth movement, which revels in languorous string harmonics, and in the third movement, which (as we have seen) shares its emphasis on open-string, double-stopped fifths with Milhaud's Second Chamber Symphony. Milhaud's heavy reliance on fifths in Machines agricoles could be meant to evoke folk harmonies and rustic, boundless space, much in the same way that Aaron Copland and other composers used open sonorities in their musical Americana. ${ }^{70}$ Yet the

\footnotetext{
${ }^{69}$ Ibid., 31.

${ }^{70}$ See in particular Denise Von Glahn, The Sounds of Place: Music and the American Cultural Landscape(Boston:
} 
open fifth also serves to destabilize the harmonic functionality of Milhaud's music, thus supporting the composer's emphasis on contrapuntal part writing and polytonality.

Occasionally in Machines agricoles, untempered enthusiasm for the sounds and spirit of nature break through. The third movement, "La Lieuse," begins with a hectic, stridently dissonant texture that prominently features the bassoon playing in its lowest register. Towards the middle of the movement, the bassoon drops out and the texture thins significantly, giving way to a clarinet figure reminiscent of birdsong (Figure 11).

Example 5: Milhaud's Machines agricoles, middle of third movement, "La Lieuse."

Listen at: http://dx.doi.org/10.3998/mp.9460447.0008.204

The leaping eleventh figure in the clarinet returns again in the fifth movement, where a much more active context obscures its reference.

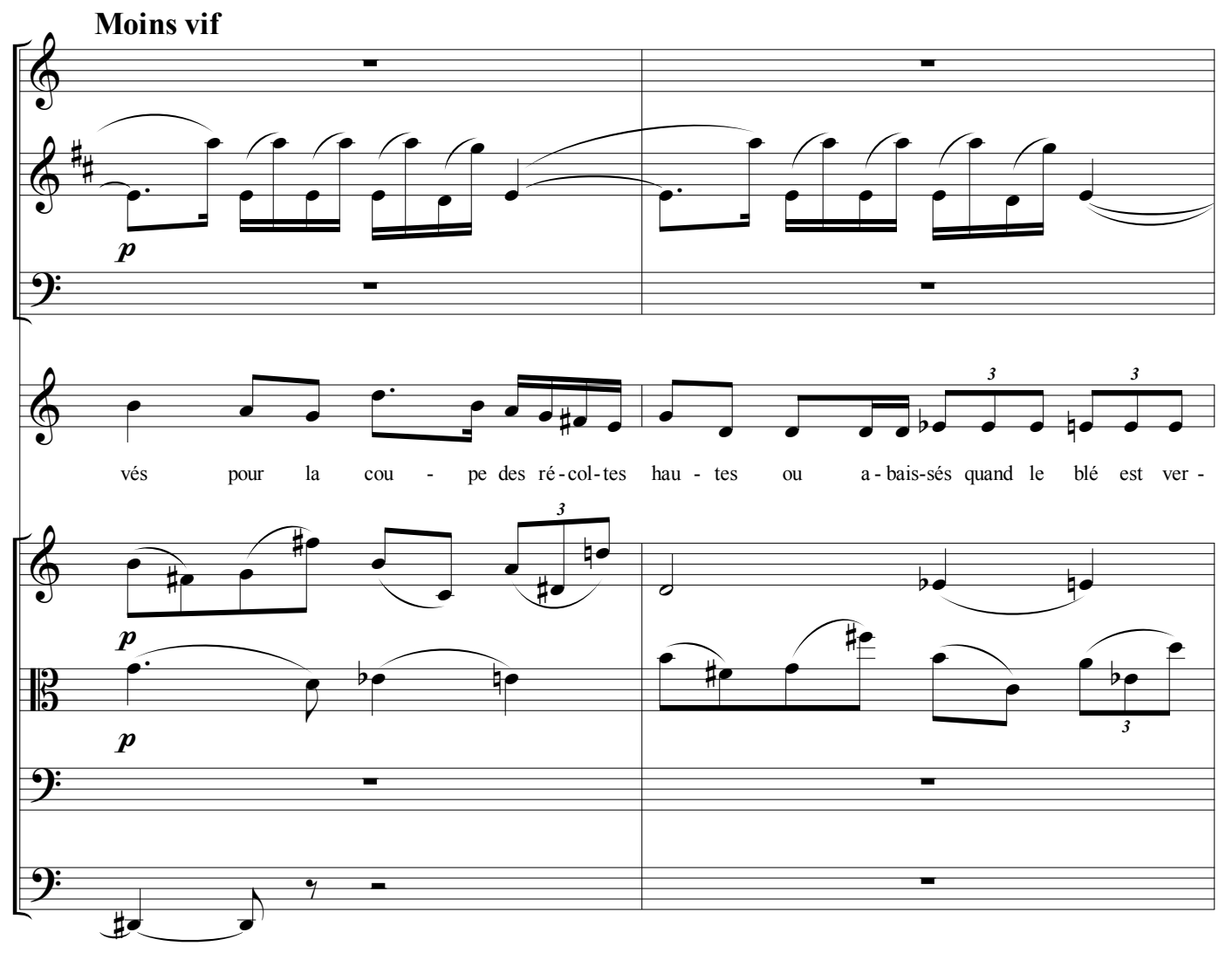

Figure 11: Machines agricoles, mvt. 3 "La Lieuse," mm. 13-14"11

Machines agricoles|6 pastorale Gesänge | für mittlere Stimme, Flöte, Klarinette, Fagott, Violine, Viola, Violoncello und Kontrabass|op. 56

(C) Copyright 1926 by Universal Edition A.G., Wien/UE 8142

Northeastern University Press, 2003); Brooks Toliver, "Eco-ing in the Canyon: Ferde Grofe's Grand Canyon Suite and the Transformation of Wilderness," Journal of the American Musicological Society 57, no. 2 (Summer 2004): 325-68; and Beth Levy, Frontier Figures: American Music and the Mythology of the American West (Berkeley: University of California Press, 2012).

${ }^{71}$ Ibid., 17. 
Milhaud saves what is perhaps the most genuine, most "escapist" pastoral moment in Machines agricoles for the very end. The sixth movement, "La Faneuse," concludes with the text, "Thanks to this machine, the wheat can be cut in the morning, made into hay later, and put inside before nightfall." Given his rough treatment of pastoral tropes prior to this moment, the strikingly prosaic, final G9 chord stands out as an exceptional moment. Yet the major mode ending does not come across as the sly wink critics hoped for. Rather, it stands as one of the only moments in the piece where Milhaud's music matches the tone of the text. As nighttime falls on the farm, the farmer finally brings in the organic materials that the machines have harvested.

\section{Example 6: Milhaud's Machines agricoles, end of final movement, "La Faneuse."}

Listen at: http://dx.doi.org/10.3998/mp.9460447.0008.204

The collection of pastoral tropes I have described serves to corroborate the sincerity in the claim by Darius and Madeleine Milhaud that the song cycle is not wholly satirical, that at least certain aspects of the piece truly "celebrate" the harvest and the farmer. Yet unabashed pastoral references are the exception rather than the rule. The second movement, "La Faucheuse," illustrates well the seemingly anti-pastoral aesthetic that has inspired audiences and critics to align Machines agricoles with machines rather than agriculture. The movement's dense texture (created in part through particularly close voicing of the different parts) masks even the most audible references to the third movement of Milhaud's Second Chamber Symphony (including the quoted melodic figure and accompaniment mentioned above). Rather than suggesting any pastoral association, the movement's thoroughly independent lines create the impression of a polytonal species counterpoint exercise (Figure 12).

\section{Example 7: Machines agricoles, mvt. 2 "La Faucheuse," beginning. \\ Listen at: http://dx.doi.org/10.3998/mp.9460447.0008.204}

The banal, anti-poetic nature of the text seems well matched with its setting: "The latest improvements to the mower have made the machine robust and practical. Friction-producing parts have been furnished with rolling pads, which explains the smoothness of the engine." ${ }^{72}$ Like the machines described in the text, Milhaud's music is robust, practical, and utterly un-Romantic. "La Faucheuse" is representative of the majority of Machines agricoles in that it marginalizes traditional pastoral tropes in favor of promoting antiRomantic, anti-Debussyste harmonic and contrapuntal language typical of Milhaud's chamber music. The forward-looking aesthetic of the piece contributes to its post-pastoral distinction: in Machines agricoles, Milhaud experiments with the notion that dense counterpoint and polytonality might be counted among the many techniques for composing pastoral works, right alongside drones, folk melodies, and peasant dance rhythms.

\footnotetext{
${ }^{72}$ Milhaud, Machines agricoles, 9-11. "Les derniers perfectionnements apportés aux Faucheuses en ont fait des machines robustes et pratiques. Toutes parties frottantes sont munies de coussinets à rouleaux; ce qui explique la légéreté de traction de ces machines."
} 

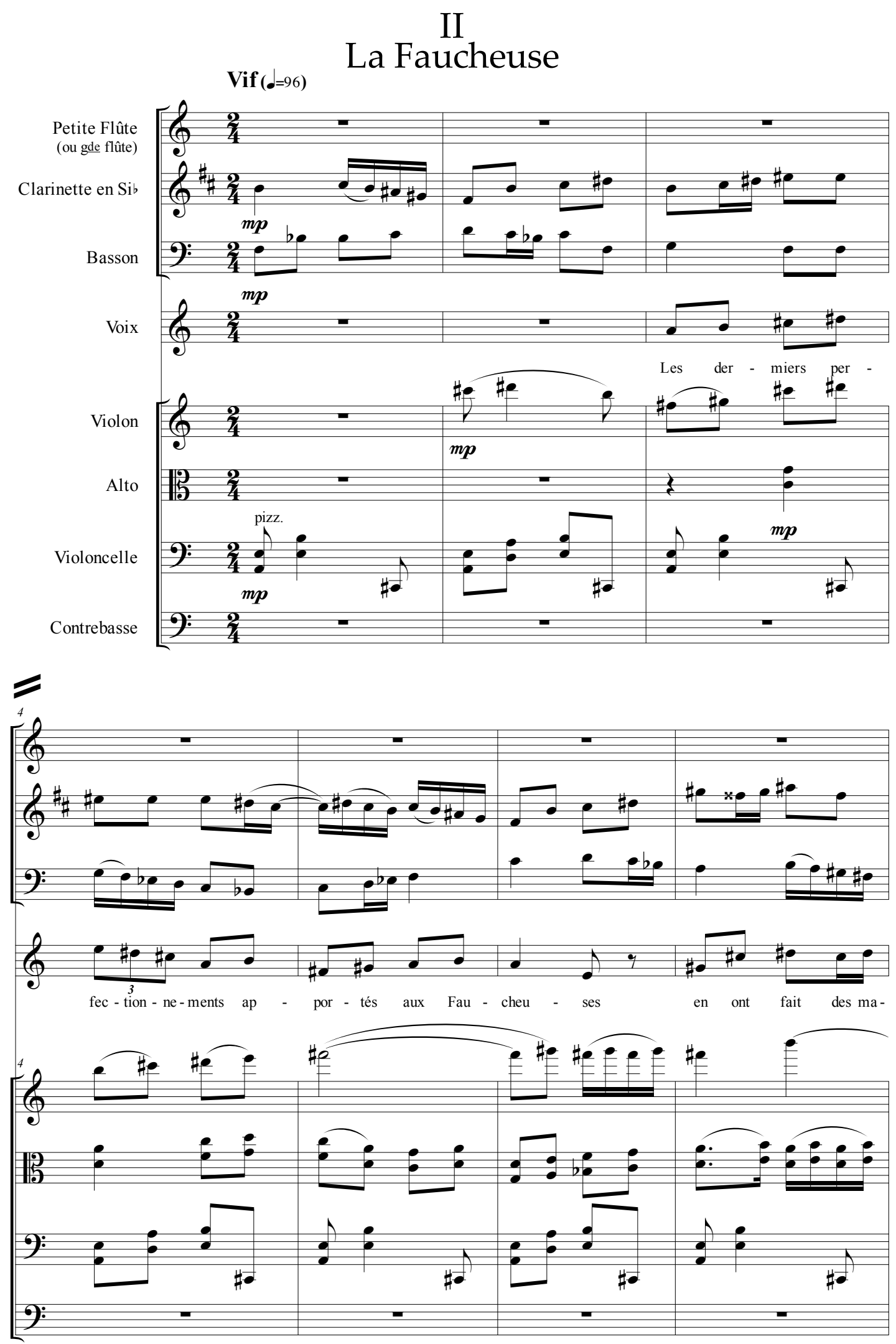

Figure 12: Machines agricoles, mvt. 2 "La Faucheuse," mm. 1-18

Machines agricoles| 6 pastorale Gesänge|für mittlere Stimme, Flöte, Klarinette, Fagott, Violine, Viola, Violoncello und Kontrabass|op. 56

(c) Copyright 1926 by Universal Edition A.G., Wien/UE 8142 


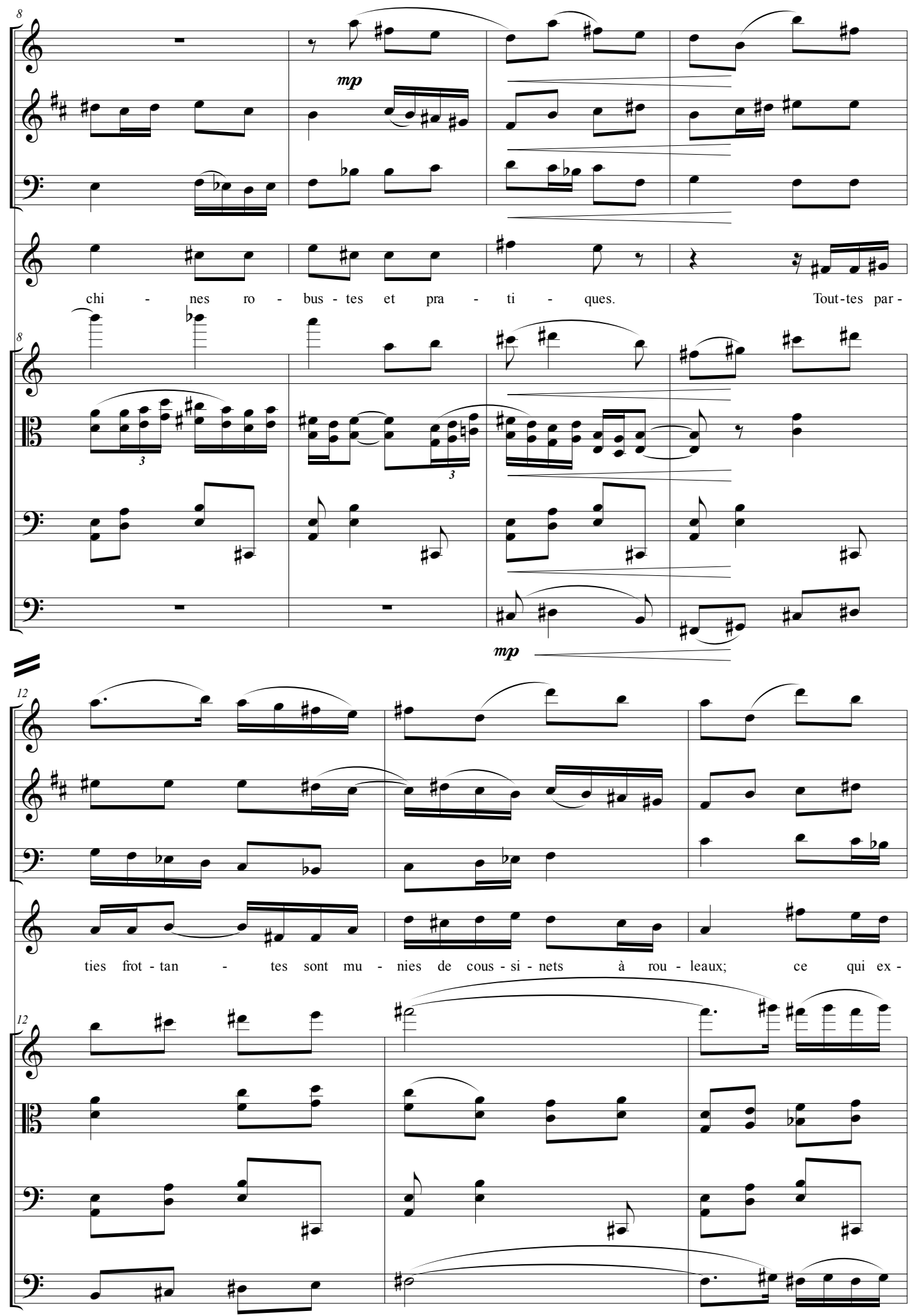

Figure 12 (cont.): Machines agricoles, mvt. 2 "La Faucheuse," mm. 1-18

Machines agricoles|6 pastorale Gesänge|für mittlere Stimme, Flöte, Klarinette, Fagott, Violine, Viola, Violoncello und Kontrabass|op. 56

(c) Copyright 1926 by Universal Edition A.G., Wien/UE 8142 

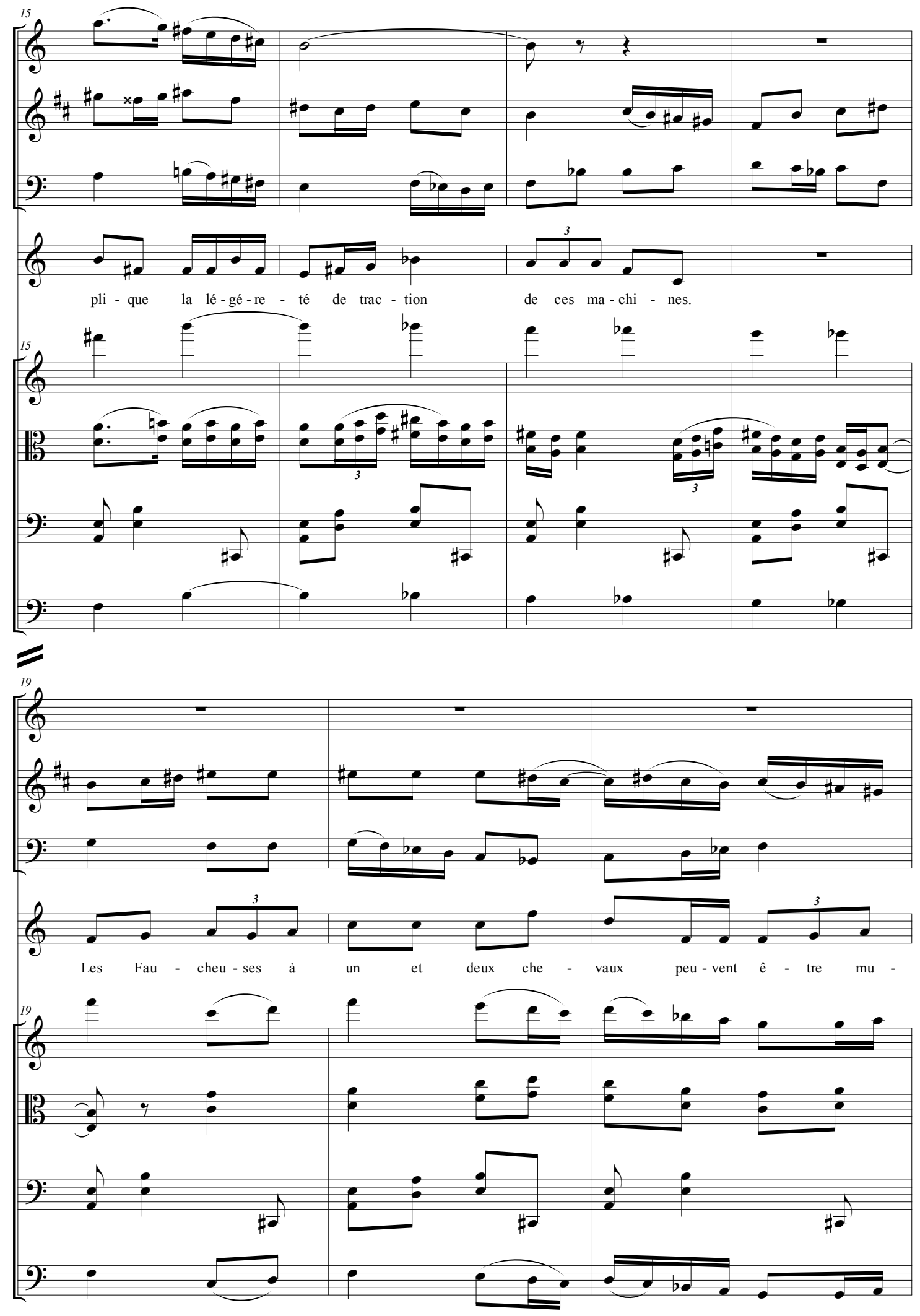

Figure 12 (cont.): Machines agricoles, mvt. 2 "La Faucheuse," mm. 1-18

Machines agricoles 6 pastorale Gesänge | für mittlere Stimme, Flöte, Klarinette, Fagott, Violine, Viola, Violoncello und Kontrabass|op. 56

(c) Copyright 1926 by Universal Edition A.G., Wien/UE 8142 
The banality of Milhaud's text and the ostensible triteness of his music (insofar as it is incomprehensibly pastoral) can be explained in terms of both musical and rural politics. Martin Cooper has argued that Machines agricoles exalts the "objective impersonal style of a shop catalogue . . at the expense of the hermetic poetry of the symbolists." ${ }^{, 73}$ Along the same lines, Nancy Perloff has explored the ways in which the adoption of "low," "popular" idioms in the music of Satie and Les Six constituted a reaction to Impressionism and a reaction to what Satie called the "slavish" adherence of Debussy's followers to a musical formula that the rebellious composer never intended to establish. ${ }^{74}$ Much of the power of Machines agricoles to shock or amuse comes from its transposition of the art of the everyday to a novel context-the pastoral-a context that had seemed impervious to such manipulations. This is what Deborah Mawer refers to when she acknowledges the piece's juxtaposition of the "mundane with the poetic." 75 Simply by choosing ungainly texts about mundane, man-made objects and by dedicating movements to Cocteau and Les Six, in Machines agricoles Milhaud already flaunted his allegiance to the anti-impressionism and anti-Debussysme of Satie and his acolytes among Les Six. Through its connections to Milhaud's chamber symphonies, Machines agricoles also signals the composer's rejection of nineteenth-century symphonic conventions and links the pastoral with the advent of neoclassicism and Cocteau's rappel à l'ordre as first articulated in the polemical pamphlet, Le Coq et l'harlequin (1918).

Due to its position within the discourses of musical and rural politics, Machines agricoles sits uneasily at the intersection of several binaries prevalent in the historiography of interwar French music. Milhaud's farm-inspired subject and aspects of his music can be understood to represent traditional, rural, provincial, conservative values. Yet the banality of the text, its earnest, polytonal setting, and the milieu in which it was performed all emphasize novelty, the urban, cosmopolitanism, and musical (as well as political) progressivism. Its recourse to latent rather than pervasive pastoral content, its dense textures, and its typically modernist, intentional unintelligibility render Machines agricoles a seemingly unlikely vehicle for political activism. Yet given its engagement with ruralité- the conception of which has been central to French national identity from Milhaud's time through our own ${ }^{76}$-alongside its anti-German, antiDebussyste musical stance, the piece could also be understood as an exemplar of early twentieth-century, avant-garde political engagement. As a post-pastoral work, Machines agricoles problematizes the pastoral while simultaneously perpetuating and adding to the genre's conventions.

\section{Memorials and Modernisms}

I have insisted throughout this essay that Machines agricoles differs from other pastoral works_and from typical, politically conservative appropriations of rural symbols—in its emphasis on the present over the past. Yet the piece cannot help but emit a whiff of nostalgia, particularly at its surprisingly traditional conclusion. But nostalgia for what, exactly? Given the postwar political context for the work, if Machines agricoles expresses any nostalgia, it is for an entire rural ecosystem, including both human and nonhuman (animal and machine) actors. Though Machines agricoles is ostensibly "about" machines, the specific

\footnotetext{
${ }^{73}$ Cooper, French Music, 190, quoted in Mawer, Darius Milhaud, 86.

${ }^{74}$ Nancy Perloff, Art and the Everyday: Popular Entertainment and the Circle of Erik Satie(New York: Clarendon Press, 1991), 12-13.

${ }^{75}$ Mawer, Darius Milhaud, 87.

${ }^{76}$ See especially Fernand Braudel, L'Identité de la France, Volume III, Les Hommes et les Choses (Paris: Flammarion, 1986).
} 
machines Milhaud describes required substantial human labor to operate-labor noticeably unavailable in the immediate aftermath of the First World War. The loss of bodies in the war translates into a loss of an important ecological resource-human farm labor-and postwar French society felt this absence keenly. In Milhaud's music, machines remain as a monument, testifying to the absence of human laborers.

Thus, even a piece entitled Machines agricoles can be understood as a very human memorial. Like Ravel's Tombeau de Couperin, which Carolyn Abbate has analyzed in terms of modernist fascination with the inanimate/animate duality of machines, Milhaud's pastorales reanimate the men who worked the machines that worked the land. ${ }^{77}$ While Milhaud's six movements are not dedicated to fallen soldiers of the Great War as is Ravel's metaphorical “tomb," the movements' connections to specific farm machinery might stand in for something similar. Following the Great War and the dramatic demographic shifts beginning decades before, the men who worked the machines are gone. In their place, the machines serve as inarticulate memorials to the recent past, their lack of humanity emphasized by the dry catalogue copy that serves as Milhaud's text. ${ }^{78}$ As straightforward as it seems to interpret Milhaud's choice of texts as a celebration of machines, the context of the piece's composition forces us to confront the likelihood that Machines agricoles functions as a site of resistance to one kind of modernity-namely, the apocalyptic destruction enabled by the advent of new martial technologies. ${ }^{79}$

Thinking of Machines agricoles as a post-pastoral and as a musical memorial to the First World War helps to make sense of its many seeming contradictions. Superficially, Machines agricoles manifests an irreconcilable tension between machine and nature, a tension that reflects and magnifies a similar tension between modernism and pastoral-as-premodern-tradition. Yet that tension is based in historiographical construct rather than reality. As a post-pastoral musical essay, Machines agricoles revels in contradictory dualities: it memorializes humans even as it celebrates simple machines; it criticizes the pastoral music of the recent and distant past while simultaneously appropriating that music's clichéd pastoral tropes; and it bears the weight of musical and social politics while seeking refuge in ostensibly hermetic, modernist compositional techniques.

Following the First World War, the desire to construct memorials to the fallen and to redress the rural crisis transcended traditional political lines, not just among public officials but also among artists. Art historian Romy Golan has noted that "far from inhabiting the margins of cultural and art-historical discourse in France," so-called "reactionary issues" regarding farming, rural preservation, and fear of technology "had a profound impact on French modernism from 1918 all the way to Vichy." ${ }^{80}$ Yet despite the ubiquity of ruralist discourses and pastoral artistic expressions in the immediate postwar environment, the politicized rural has been absent from music histories of modernism. The composers labeled "modernist" are more commonly portrayed as unrelenting cosmopolitans, prescient individuals fascinated by disruptive technologies and ever oriented toward a technologized future. Recent work in ecocritical theory has drawn attention to how artists in the twentieth century have engaged with issues of

\footnotetext{
77 Carolyn Abbate, “Outside Ravel's Tomb,” Journal of the American Musicology Society 52, no. 3 (Autumn 1999): $465-530$.

${ }^{78}$ Milhaud was by no means the only composer whose pastoral music memorialized those lost in the First World War. For instance, Ralph Vaughan Williams acknowledged that his "Pastoral" Symphony No. 3 emerged in part from Williams's experiences in the ambulance corps during the war. See Eric Saylor, “It's Not Lambkins Frisking At All': English Pastoral Music and the Great War," Musical Quarterly 91 (Spring 2008): 39-59.

${ }^{79}$ Alex Rehding has described recent interest in literature and film featuring apocalyptic scenarios as a manifestation of ecological anxiety around the destructive capacity of modern technology. See Rehding, "Ecomusicology between Apocalypse and Nostalgia," Journal of the American Musicological Society 64, no. 2 (Summer 2011): 409-14.

${ }^{80}$ Romy Golan, Modernity and Nostalgia, ix.
} 
conservation and industrialization through work set in pastoral contexts. Golan, for instance, has noted that the ostensible "modernist fantasy of the tabula rasa" did not dominate France's postwar reconstruction efforts; rather, it was the rural vernacular that seemed to offer the best chance for an authentic reconstruction. ${ }^{81}$ The many pieces of traditional landscape art painted in the 1920s show that artists, too, engaged in a process of "rusticizing the modern"; that is, emphasizing rural scenes with contemporary aesthetics, and thus expressing postwar nostalgia for simpler times. ${ }^{82}$ Rather than criticizing farm machinery or celebrating its power, speed, and violence as the Futurists would, Milhaud co-opted the pastoral to imbue six machines agricoles with a soul. He rendered them organic, allowing these "great, colorful, iron insects" to flit about productively and unthreateningly. Along the way, Milhaud also managed to modernize the rustic, bringing a long-present and increasingly necessary man-made agent of small farms into the pastoral fold.

\section{Bibliography}

Abbate, Carolyn. "Outside Ravel's Tomb.” Journal of the American Musicology Society 52, no. 3 (Autumn 1999): 465-530. http://dx.doi.org/10.2307/831791.

Allen, Aaron S. "Ecomusicology: Ecocriticism and Musicology." Journal of the American Musicological Society 64, no. 2 (Summer 2011): 391-94. http://dx.doi.org/10.1525/jams.2011.64.2.391.

—_. "Symphonic Pastorals." Green Letters: Studies in Ecocriticism 15 (2011): 22-42.

“Appareils de prothèse et machines agricoles pour mutilés de la guerre," La Lanterne, June 17, 1919. Accessed November 23, 2013. http://gallica.bnf.fr.

Aubert, Marcel. Trésors d'art de la France meurtrie. Paris: Gazette des Beaux Arts, 1921.

Braudel, Fernand. L'Identité de la France. Paris: Flammarion, 1986.

Brinkmann, Reinhold. Late Idyll: The Second Symphony of Johannes Brahms. Translated by Peter Palmer. Cambridge, MA: Harvard University Press, 1995.

Buell, Lawrence. The Environmental Imagination: Thoreau, Nature Writing, and the Formation of American Culture. Cambridge, MA: Harvard University Press, 1995.

Cocteau, Jean. Le Coq et l'harlequin. London: Egoist Press, 1921.

Collaer, Paul. Paul Collaer: Correspondance avec des amis musiciens, edited by Robert Wangermée. Liège: Pierre Mardaga, 1996.

—. Darius Milhaud. Geneva: Slatkine, 1982.

Cooper, Martin. French Music from the Death of Berlioz to the Death of Fauré. London: Oxford University Press, 1951.

Davis, Mary C. Classic Chic: Music, Fashion, and Modernism. Berkeley: University of California Press, 2006.

Erik Satie. London: Reaktion, 2007.

de Schloezer, Boris. Comprendre la musique: Contributions à La Nouvelle revue française et à La Revue musicale (1921-1956), edited by Timothée Picard. Rennes: Presses Universitaires de Rennes, 2011.

\footnotetext{
${ }^{81}$ Ibid.

${ }^{82}$ Ibid., 23.
} 
Dumesnil, Réné. La Musique en France entre les deux guerres, 1918-1939. Paris: Editions du Milieu du Monde, 1946.

Ettin, Andrew V. Literature and the Pastoral. New Haven, CT: Yale University Press, 1984.

Fulcher, Jane. "Musical Style, Meaning, and Politics in France on the Eve of the Second World War." Journal of Musicology 13, no. 4 (Autumn 1995): 425-53. http://dx.doi.org/10.2307/763894.

—_. The Composer as Intellectual: Music and Ideology in France 1914-1940. New York: Oxford University Press, 2005.

Gavignaud, Geneviève. Les Campagnes en France au XXe siècle (1914-1989). Paris: Éditions Ophrys, 1990.

Gervais, Michel, Marcel Jollivet, and Yves Tavernier. La Fin de la France paysanne. Vol 4. of Histoire de la France rurale, edited by Georges Duby and Armand Wallon. Paris: Éditions du Seuil, 1977.

Gifford, Terry. Pastoral. New York: Routledge, 1999.

Golan, Romy. Modernity and Nostalgia: Art and Politics in France between the Wars. New Haven, CT: Yale University Press, 1995.

Halbreich, Harry. Arthur Honegger. Translated by Reinhard G. Pauly. Portland: Amadeus Press, 1999.

Harding, James. The Ox on the Roof: Scenes from Musical Life in Paris in the Twenties. New York: St. Martin's Press, 1972.

Hurard-Viltard, Eveline. Le groupe des Six ou le matin d'un jour de fête. Paris: Méridiens/Klinksieck, 1987.

James, David, and Philip Tew, eds. New Versions of Pastoral: Post-Romantic, Modern, and Contemporary Responses to Tradition. Madison: Fairleigh Dickinson University Press, 2009.

Kelly, Barbara. Tradition and Style in the Works of Darius Milhaud 1912-1939. Aldershot: Ashgate, 2003.

Levy, Beth. Frontier Figures: American Music and the Mythology of the American West. Berkeley: University of California Press, 2012. http://dx.doi.org/10.1525/california/9780520267763.001.0001.

Marx, Leo. The Machine in the Garden: Technology and the Pastoral Ideal in America. Oxford: Oxford University Press, 1964.

Mawer, Deborah. "Ballet and the Apotheosis of the Dance." In The Cambridge Companion to Ravel, edited by Deborah Mawer, 140-62. Cambridge: Cambridge University Press, 2000. http://dx.doi.org/10.1017/CCOL9780521640268.009.

—_. Darius Milhaud: Modality \& Structure in Music of the 1920s. Aldershot: Ashgate Press, 1997.

Mellers, Wilfrid. Singing in the Wilderness: Music and Ecology in the Twentieth Century. Urbana: University of Illinois Press, 2001.

Milhaud, Darius. Ma Vie heureuse. Paris: Belfond, 1973.

—. Machines Agricoles. Vienna: Universal Edition, 1926.

—_. Petite Symphonie No. 2. Vienna: Universal Edition, 1925.

Moore, Christopher. "Poulenc's Versions of Pastoral." Paper presented at Rethinking Poulenc: 50 Years On (conference), Keele University, June 22, 2014.

Nichols, Roger. The Harlequin Years. Berkeley: University of California Press, 2002.

Peattie, Thomas. "In Search of Lost Time: Memory and Mahler's Broken Pastoral." In Mahler and His World, edited by Karen Painter, 185-98. Princeton: Princeton University Press, 2002. 
Peer, Shanny. France on Display: Peasants, Provincials, and Folklore in the 1937 Paris World's Fair. Albany: State University of New York Press, 1998.

Perloff, Nancy. Art and the Everyday: Popular Entertainment and the Circle of Erik Satie. New York: Clarendon Press, 1991.

Rehding, Alexander. "Ecomusicology between Apocalypse and Nostalgia." Journal of the American Musicological Society 64, no. 2 (Summer 2011): 409-14. http://dx.doi.org/10.1525/jams.2011.64.2.409.

Sales, Roger. English Literature in History 1780-1830: Pastoral and Politics. London: Hutchinson, 1983.

Saylor, Eric. "It's Not Lambkins Frisking At All': English Pastoral Music and the Great War." Musical Quarterly 91 (Spring 2008): 39-59. http://dx.doi.org/10.1093/musqtl/gdn030.

Taruskin, Richard. "Back to Whom? Neoclassicism as Ideology." $19^{\text {th }}$-Century Music 16, no. 3 (Spring 1993): 286-302.

Toliver, Brooks. "Eco-ing in the Canyon: Ferde Grofe's Grand Canyon Suite and the Transformation of Wilderness," Journal of the American Musicological Society 57, no. 2 (Summer 2004), 325-68. http://dx.doi.org/10.1525/jams.2004.57.2.325.

Von Glahn, Denise. The Sounds of Place: Music and the American Cultural Landscape. Boston: Northeastern University Press, 2003.

Watkins, Glenn. Pyramids at the Louvre: Music, Culture, and Collage from Stravinsky to the Postmodernists. Cambridge, MA: Harvard University Press, 1994. http://dx.doi.org/10.4159/harvard.9780674437418.

Watkins, Holly. "The Pastoral After Environmentalism: Nature and Culture in Stephen Albert's Symphony: RiverRun." Current Musicology 84 (Fall 2007): 7-24.

Weber, Eugen. The Hollow Years: France in the 1930s. New York: W. W. Norton \& Company, 1994.

Will, Richard. The Characteristic Symphony in the Age of Haydn and Beethoven. Cambridge: Cambridge University Press, 2002. http://dx.doi.org/10.1017/CBO9780511481895.

Williams, Raymond. "Pastoral and Counter-Pastoral." Critical Quarterly 10 (1967): 277-90. http://dx.doi.org/10.1111/j.1467-8705.1968.tb01989.x.

Wright, Gordon. Rural Revolution in France: The Peasantry in the Twentieth Century. Stanford: Stanford University Press, 1964. 


\begin{abstract}
Darius Milhaud's song cycle Machines agricoles (1919) has long been considered a joke among critics and scholars. In the piece, Milhaud sets mundane, unpoetic excerpts from farm machine catalogues with his characteristic polytonal, polyrhythmic musical language. The earnestness of the setting clashes with the piece's awkward texts, and both seemingly contradict the work's subtitle, "Six Pastorals for Voice and Seven Instruments." Although Milhaud protested against the one-sided critical reception of his work, claiming that he had created an unironic celebration of rural life, the piece's pastoral pretentions remain unexamined. I argue that Milhaud's invocation of the pastoral genre in Machines agricoles is not merely an iconoclastic, Dadaist provocation. Rather, it engages in productive critique of the pastoral tradition while subtly echoing politically inflected discourses concerning the challenges facing rural France at the time, challenges that deepened following the ecological and demographic devastation of the First World War. A close reading of Machines agricoles reveals numerous musical references to the pastoral tradition, albeit in a context that updates or rejects Romantic idealizations of rural ecologies. Drawing on literary ecocriticism, I demonstrate how Machines agricoles articulates a "post-pastoral" perspective on the complicated symbiosis between man, machine, and nature in early twentieth-century France.
\end{abstract}

